\section{Pacific Northwest}

National Laboratory

Operated by Battelle for the

U.S. Department of Energy

\title{
Effect of Design Changes on Remote- Handled Trench Waste Form Release Calculations
}

\author{
D.H. Bacon \\ B.P. McGrail
}

August 2002

Prepared for the U.S. Department of Energy

under Contract DE-AC06-76RL01830

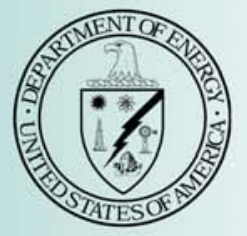




\title{
DISCLAIMER
}

This report was prepared as an account of work sponsored by an agency of the United States Government. Neither the United States Government nor any agency thereof, nor Battelle Memorial Institute, nor any of their employees, makes any warranty, express or implied, or assumes any legal liability or responsibility for the accuracy, completeness, or usefulness of any information, apparatus, product, or process disclosed, or represents that its use would not infringe privately owned rights. Reference herein to any specific commercial product, process, or service by trade name, trademark, manufacturer, or otherwise does not necessarily constitute or imply its endorsement, recommendation, or favoring by the United States Government or any agency thereof, or Battelle Memorial Institute. The views and opinions of authors expressed herein do not necessarily state or reflect those of the United States Government or any agency thereof.

\author{
PACIFIC NORTHWEST NATIONAL LABORATORY \\ operated by \\ BATTELLE \\ for the \\ UNITED STATES DEPARTMENT OF ENERGY \\ under Contract DE-AC06-76RL01830
}

Printed in the United States of America
Available to DOE and DOE contractors from the Office of Scientific and Technical Information,
P.O. Box 62, Oak Ridge, TN 37831-0062;
ph: (865) 576-8401
fax: (865) 576-5728
email: reports@adonis.osti.gov

\author{
Available to the public from the National Technical Information Service, \\ U.S. Department of Commerce, 5285 Port Royal Rd., Springfield, VA 22161 \\ ph: (800) 553-6847 \\ fax: (703) 605-6900 \\ email: orders@ntis.fedworld.gov \\ online ordering: http://www.ntis.gov/ordering.htm
}

This document was printed on recycled paper. 


\section{Effect of Design Changes on Remote-Handled Trench Waste Form Release Calculations}

D. H. Bacon

B. P. McGrail

August 2002

Prepared for the U.S. Department of Energy under Contract DE-AC06-76RL01830

Pacific Northwest National Laboratory

Richland, Washington 99352 



\section{Summary}

A set of reactive chemical transport calculations was conducted with the Subsurface Transport over Reactive Multiphases (STORM) code to evaluate the long-term performance of a representative lowactivity waste glass in a shallow subsurface disposal system on the Hanford Site. One-dimensional simulations were conducted for a period of 20,000 years. The simulations predict a lower release rate for the new three-layer trench design $(0.605 \mathrm{ppm} / \mathrm{yr})$ than for the old four-layer trench design $(0.726 \mathrm{ppm} / \mathrm{yr})$.

Because the glass corrosion rate is significantly higher at the backfill/glass interfaces, having one less interface offsets the effect of the slightly higher $\mathrm{pH}$ better than the old four-layer design. The differences between the old and new trench designs were much less significant than those due to variations in recharge rate. 



\section{Contents}

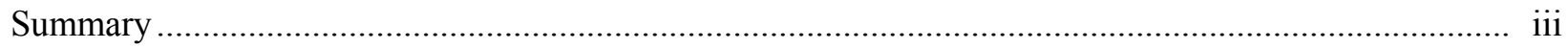

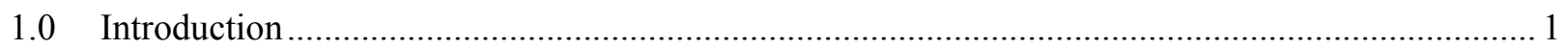

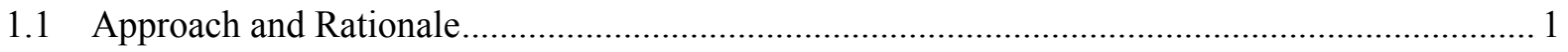

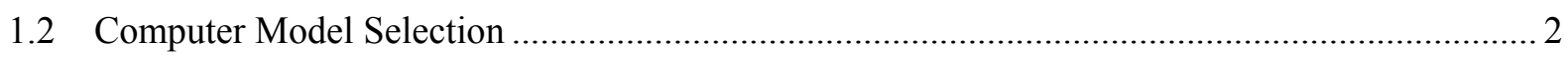

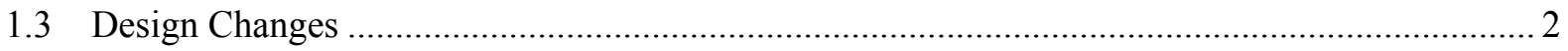

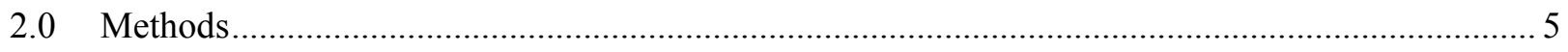

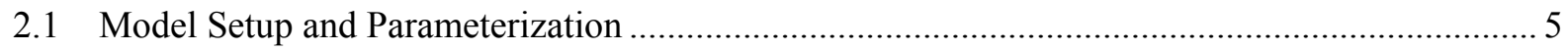

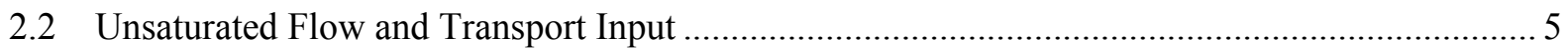

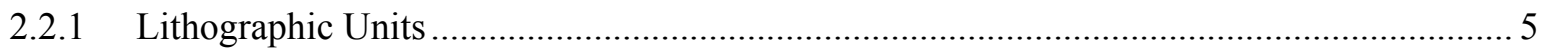

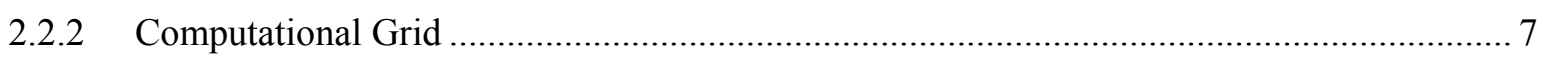

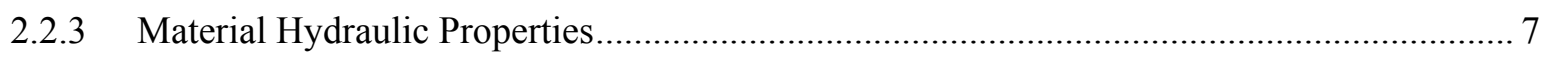

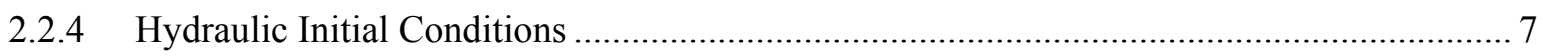

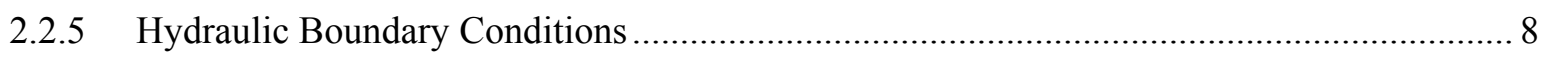

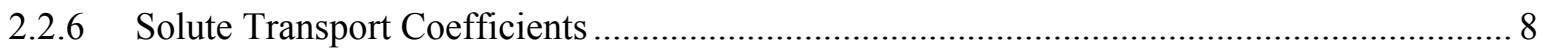

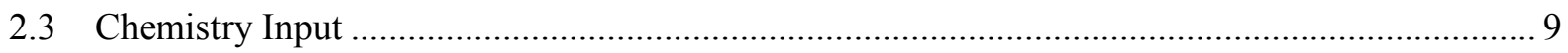

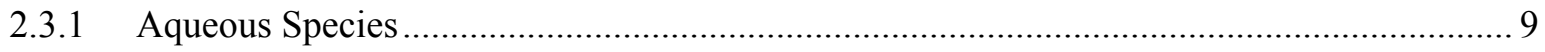

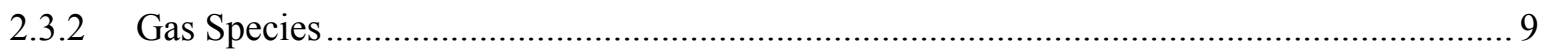

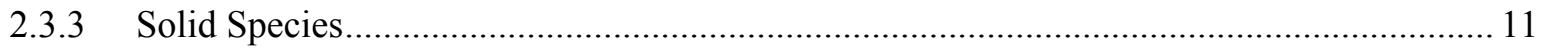

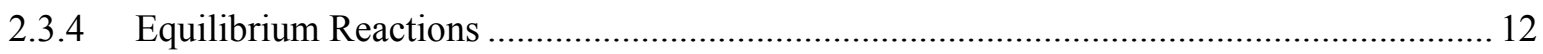

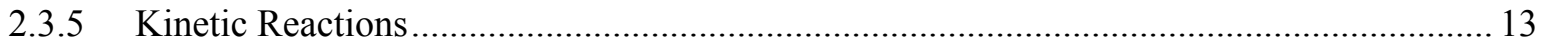

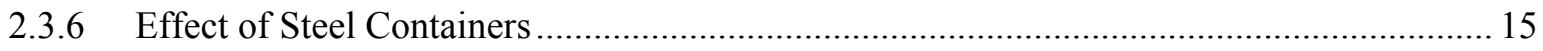

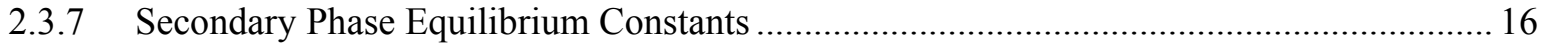

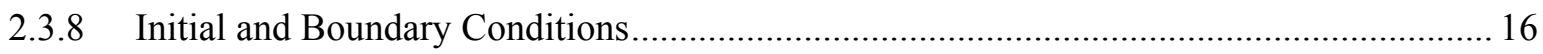

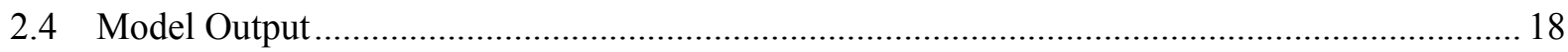

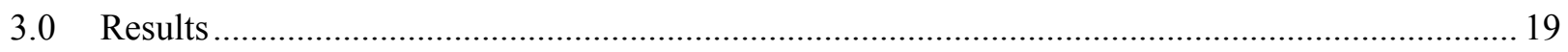

3.1 Comparison of Cases WF31 and WF25-Old Versus New Trench Designs ............................ 19

3.2 Comparison of Cases WF31 Through WF35 - Variations in Recharge Rate............................ 20

3.3 Comparison of Cases WF33, WF36 and WF37_Effect of Missing Layers............................ 20

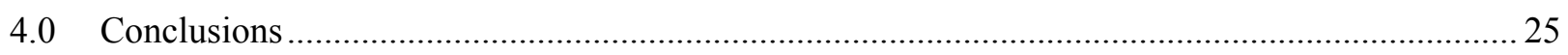

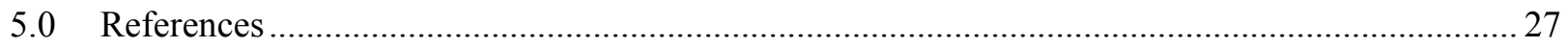




\section{Figures}

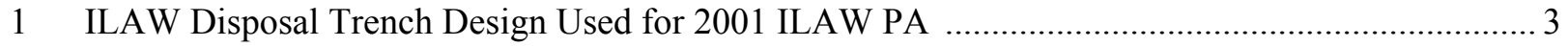

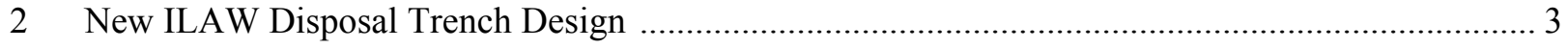

3 Lithographic Units for 1-D Old RH Trench Waste Form Release Simulations................................ 6

4 Lithographic Units for 1-D New RH Trench Waste Form Release Simulations ............................. 6

5 Technetium Fluxes Through Bottom of Disposal Facility for Different Recharge Rates ............... 20

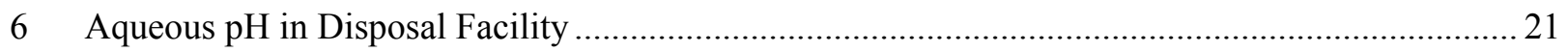

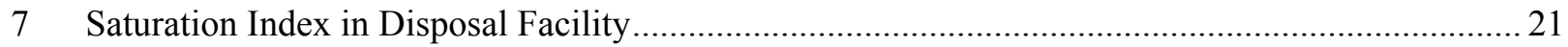

8 Technetium Fluxes Through Bottom of Disposal Facility for Various Recharge Rates ................. 22

9 Technetium Concentrations in Disposal Facility ....................................................................... 22

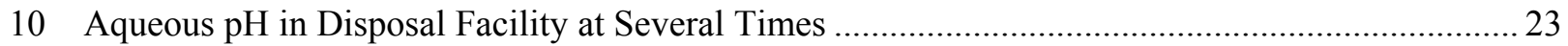

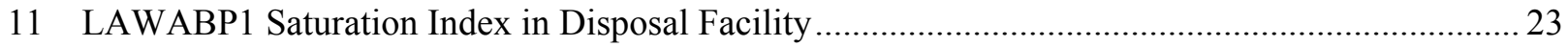

\section{Tables}

1 Relative Volume of Solid Species in Material Zones .................................................................. 6

2 Particle Radius of Solid Species in Material Zones ...................................................................... 7

3 Material Hydraulic Properties Used in Simulations ............................................................... 7

4 Key Aqueous Species Produced by the Dissolution of Calcite and LAWABP1 Glass

Containing Trace Amounts of I, Tc, Se, U, and Pu in Deionized Water ........................................ 10

5 Composition (Mole Fraction) of ILAW Glasses Used in Simulations .......................................... 11

6 Composition of Native and Other Surrounding Materials Used in Simulations............................. 11

7 Composition of Secondary Minerals Used in Simulations ............................................................ 12

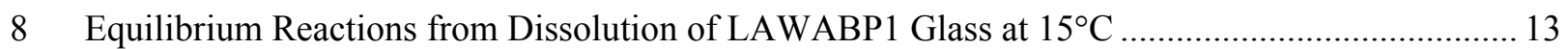

9 Summary of Kinetic Rate Parameters Used for Glasses .......................................................... 15

10 Secondary Phase Reaction Network for LAWABP1 Glass ....................................................... 16

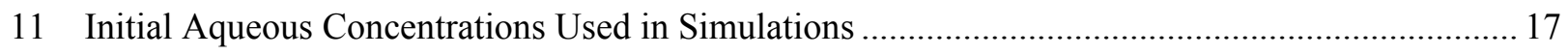

12 List of 1-D Waste Form Sensitivity Cases .............................................................................. 19

13 Summary of New One-Dimensional ILAW Sensitivity Cases ..................................................... 26 


\subsection{Introduction}

The Hanford Site in southeastern Washington State has been used extensively by the U.S. Department of Energy (DOE) to produce nuclear materials for the U.S. strategic defense arsenal. A large inventory of radioactive and mixed waste has accumulated in 177 buried single- and double-shell tanks. Liquid waste recovered from the tanks will be pretreated to separate the low-activity fraction from the high-level and transuranic wastes. The low-activity waste (LAW) will be immobilized in glass and placed in a nearsurface disposal system on the Hanford Site. Vitrifying the LAW will generate over $160,000 \mathrm{~m}^{3}$ of glass. The volume of immobilized low-activity waste (ILAW) at Hanford is among the largest within the DOE complex and comprises one of the largest inventories of long-lived radionuclides planned for disposal in a low-level waste facility (approximately 2.4 million curies total activity). Before the ILAW can be disposed, DOE must approve a performance assessment (PA), which is a document that describes the long-term impacts of the disposal facility on public health and environmental resources. A sound scientific basis for determining the long-term release rates of radionuclides from LAW glasses must be developed if the PA is to be accepted by regulators and stakeholders.

\subsection{Approach and Rationale}

The 1998 version of the ILAW PA (Mann et al. 1998) showed that a key variable in the analysis is the waste form release rate, which must be calculated over a period of thousands of years. To conduct this calculation, we used a methodology in which the waste form release rate was evaluated by modeling the basic physical and chemical processes that are known to control dissolution behavior instead of using empirical extrapolations from laboratory "leaching" experiments commonly used in other PAs. We adopted this methodology because the dissolution rate, and hence radionuclide release rate, from silicate glasses is not a static variable - a constant that can be derived independently of other variables in the system. Glass dissolution rate is a function of three variables (neglecting glass composition itself): temperature, $\mathrm{pH}$, and composition of the fluid contacting the glass (McGrail et al. 2001).

The temperature of the ILAW disposal system is a known constant. However, both the $\mathrm{pH}$ and the composition of the fluid contacting the glass are variables that are affected by flow rate, reactions with other engineered materials, gas-water equilibria, secondary phase precipitation, alkali ion exchange, and dissolution of the glass itself (a classic feedback mechanism). Consequently, glass dissolution rates will vary both in time and as a function of position in the disposal system. There is no physical constant such as a "leach rate" or radionuclide release rate parameter that can be assigned to a glass waste form in such a dynamic system.

One of the principal purposes of the ILAW PA is to provide feedback to engineers regarding the impacts of design options on disposal system performance. A model based on the empirical release behavior of the waste form could not provide this information. For example, we have found little effect on waste form performance regardless of whether stainless or cast steel is used for the waste form pour canister. However, significant impacts have been observed when large amounts of concrete are used in constructing vaults for ILAW. The concrete raises the $\mathrm{pH}$ of the pore water entering the waste packages and thereby increases glass corrosion. 
Unfortunately, the robust methodology that was used comes with additional requirements. First, detailed information is needed regarding the reaction mechanisms controlling the dissolution behavior of the waste form. A significant number of additional laboratory experiments are required to obtain the rate law parameters needed for the models used for our simulations. Second, the model now being used (described in Section 2) is markedly more complex because of its ability to simulate reactive transport coupled with heterogeneous, unsaturated flow. Execution times with today's fastest workstations can take days for one-dimensional (1-D) simulations and months for two-dimensional (2-D) simulations; three-dimensional (3-D) simulations can be attempted only on today's most sophisticated massively parallel computers. Still, we believe the benefits, particularly the technical defensibility of the methodology and results, far outweigh the penalties.

\subsection{Computer Model Selection}

The code selection criteria and selection process used are documented in Selection of a Computer Code for Hanford Low-Level Waste Engineered-System Performance Assessment (McGrail and Bacon 1998). The needed capabilities were identified from an analysis of the important physical and chemical processes expected to affect LAW glass corrosion and the mobility of radionuclides. The available computer codes with suitable capabilities were ranked in terms of the feature sets implemented in the code that match a set of physical, chemical, numerical, and functional capabilities needed to assess release rates from the engineered system. The highest-ranked computer code was found to be the STORM code developed at Pacific Northwest National Laboratory (PNNL) for evaluating arid land disposal sites. The verification studies for STORM are documented in Subsurface Transport over Reactive Multiphases (STORM): A General, Coupled Nonisothermal Multiphase Flow, Reactive Transport, and Porous Medium Alteration Simulator, Version 2, User's Guide (Bacon et al. 2000).

\subsection{Design Changes}

The simulations for the 2001 ILAW PA were based on the trench and waste package design shown in Figure 1. New ILAW waste form release simulations have been devised to reflect the newest facility and waste package information (Figure 2). The new trench dimensions have remained essentially equivalent to those used in the 2001 ILAW PA. The maximum depth of the new trench is $17.7 \mathrm{~m}$; the old trench was $17 \mathrm{~m}$. The dimensions of the trench at grade level are $80 \mathrm{~m}$ by $260 \mathrm{~m}$.

The waste packages are grouped into long blocks that extend the length of each trench. The old waste package design is a 1.4-m cube; the new waste package has an outside diameter of $1.22 \mathrm{~m}$ and a height of $2.3 \mathrm{~m}$ (Auclair and Thien 2000). The old waste package is assumed to be $85 \%$ filled with glass and the new waste package $87 \%$ filled with waste glass (i.e., to a height of $2.0 \mathrm{~m}$ ). The thickness of the stainlesssteel walls of both the old and new waste package containers is assumed to be $0.010 \mathrm{~m}$. The old trench design places the waste packages in four layers, in groups of 6 or 7 packages, with $1 \mathrm{~m}$ of backfill between layers (Figure 1). The new trench design places the waste packages in three layers, in groups of 6 to 10 packages, with $1 \mathrm{~m}$ of backfill between layers (Figure 2). 


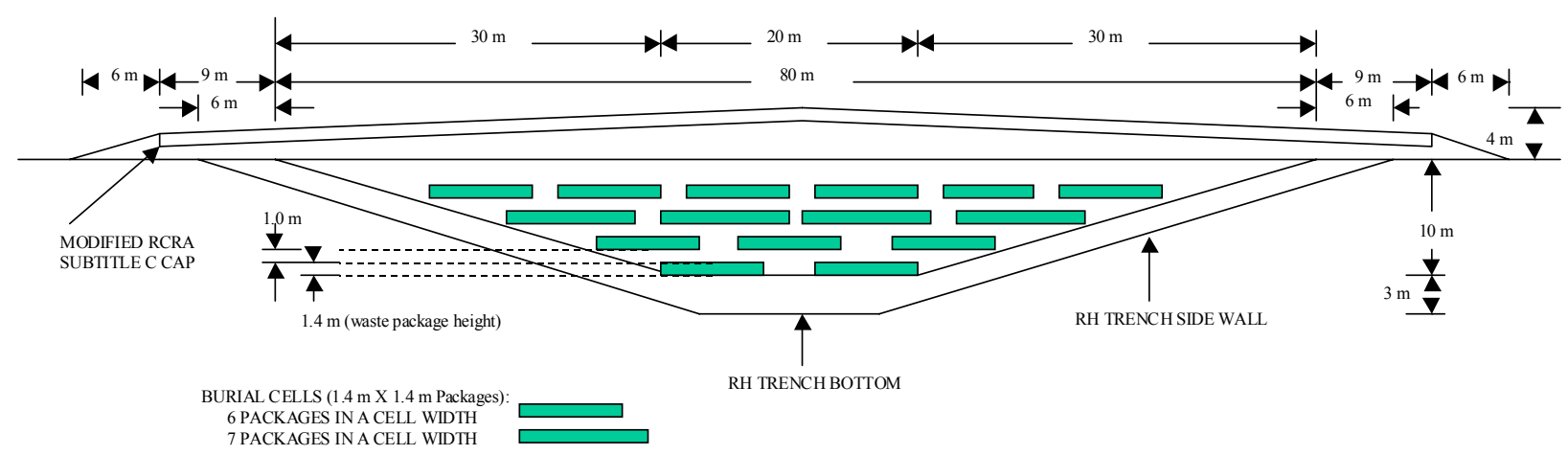

Figure 1. ILAW Disposal Trench Design Used for 2001 ILAW PA (Mann et al. 2001)

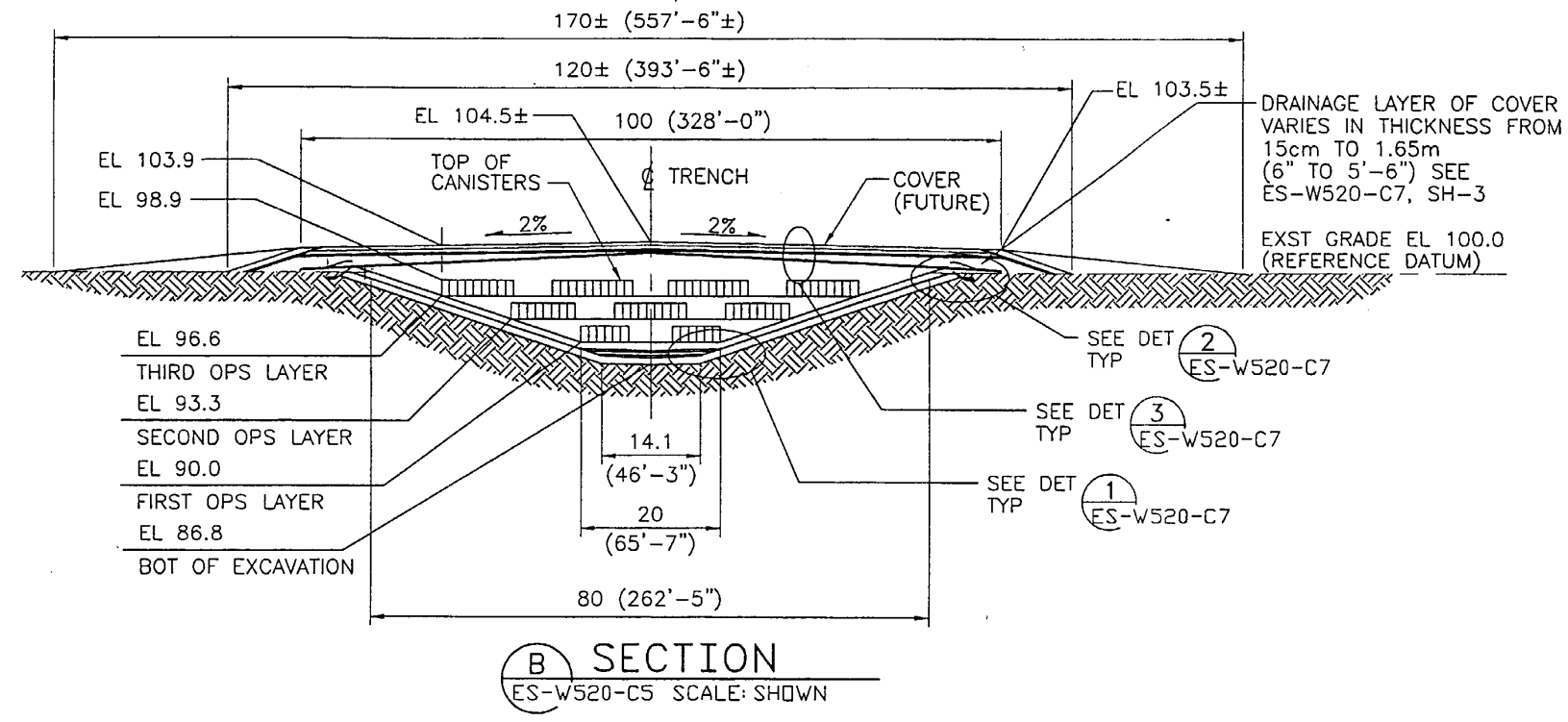

Figure 2. New ILAW Disposal Trench Design (Burbank 2001) 


\subsection{Methods}

\subsection{Model Setup and Parameterization}

This section details the data in the STORM code input data file (Bacon et al. 2000). Input data to STORM can be divided into two parts: 1) unsaturated flow and transport and 2) chemistry. Entries for unsaturated flow and transport include lithographic units, hydraulic properties, hydraulic initial conditions, and hydraulic boundary conditions. These data were principally defined from facility design documents (Puigh 1999), the near-field hydraulic properties data package (Meyer and Serne 1999), or the far-field hydraulic properties data package (Khaleel 1999). STORM was used to compute the flow field in the near-field region based on hydraulic properties for the materials and specified initial and boundary conditions. Chemistry input to STORM consists of entries for aqueous species, gas species, solid species, equilibrium reactions, kinetic reactions, and geochemical initial and boundary conditions. Each of these inputs is described in the following sections.

\subsection{Unsaturated Flow and Transport Input}

\subsubsection{Lithographic Units}

To establish a consistent framework for overlaying a computational grid on the spatial domain of interest, a set of material zones or lithographic units is established with similar hydrogeological and geochemical properties. These zones are usually related to disposal design components, geologic formations, or geologic facies determined from borehole analyses. However, because there are practical limits to the resolution of the model grid, material zones may also include combinations of materials that are assigned uniform hydraulic and/or chemical properties. These materials were classified into appropriate zones as a part of the near-field hydraulics data package (Meyer and Serne 1999).

The 1-D remote-handled (RH) trench simulations encompass a vertical profile near the center of a single trench. The simulations for the 2001 ILAW PA had four $1.4 \mathrm{~m}$ glass layers spaced $1 \mathrm{~m}$ apart (Figure 3). In the new 1-D simulations, there are three 2.3-m glass layers spaced $1 \mathrm{~m}$ apart (Figure 4).

For each lithographic unit, a list of the solid species that compose the unit is required. For each solid, the relative volume and particle radius are needed. Values for these variables for each lithographic unit are listed in Tables 1 and 2. The waste package is assumed to consist of a 304L stainless steel container filled with LAWABP1 waste glass. The old trench simulations included a steel waste package container and assumed that the material representing the waste packages was $85 \%$ glass by volume. The new ILAW trench simulations assume waste packages with $87 \%$ glass by volume for a $2.0-\mathrm{m}$ fill level for the 2.3-m-high waste package. The old container is assumed to have an average thickness of $0.75 \mathrm{~cm}$; the new container is assumed to have an average thickness of $1 \mathrm{~cm}$. For Hanford sands and backfilled soil, petrologic and particle size data were obtained from the near-field hydrology data package (Meyer and Serne 1999). The backfilled soil is assumed to consist of $40 \%$ albite, $40 \%$ quartz, $10 \% \mathrm{~K}$-feldspar, and 10\% illite (Mann et al. 1998). 


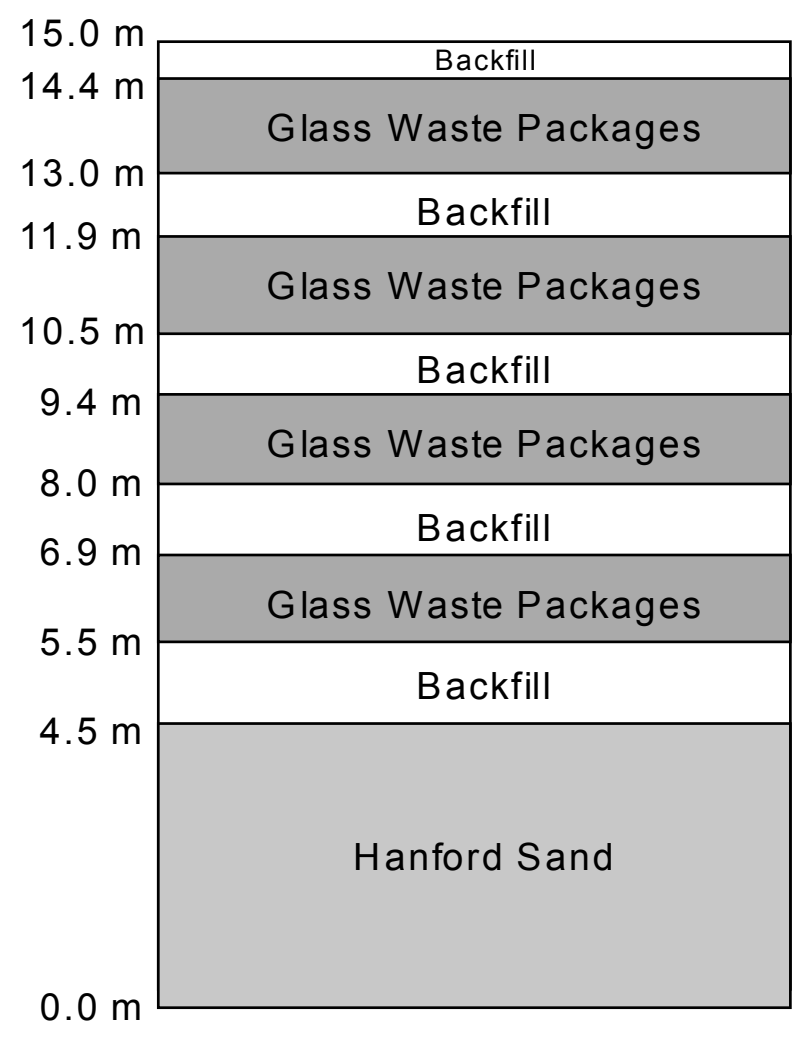

Figure 3. Lithographic Units for 1-D Old RH Trench Waste Form Release Simulations

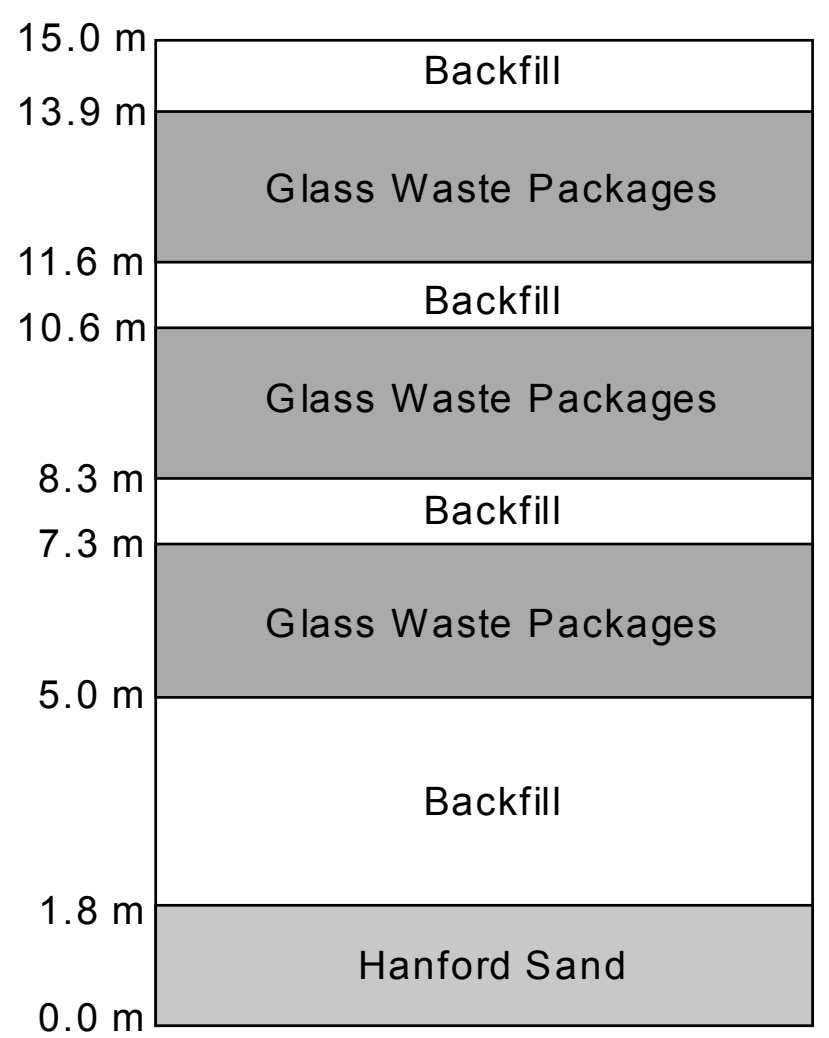

Figure 4. Lithographic Units for 1-D New RH Trench Waste Form Release Simulations

Table 1. Relative Volume of Solid Species in Material Zones

\begin{tabular}{||l|l|l|l|l|l|l|c|}
\hline & $\begin{array}{c}\text { ILAW } \\
\text { Glass }\end{array}$ & 304L SS & Quartz & Albite & $\begin{array}{c}\text { K- } \\
\text { Feldspar }\end{array}$ & Illite & $\begin{array}{c}\text { Inert } \\
\text { Material }\end{array}$ \\
\hline Waste package (old) & 0.85 & 0 & 0 & 0 & 0 & 0 & 0.15 \\
\hline Waste package (new) & 0.87 & 0 & 0 & 0 & 0 & 0 & 0.13 \\
\hline Container (old) & 0.85 & 0.15 & 0 & 0 & 0 & 0 & 0 \\
\hline Container (new) & 0.80 & 0.20 & 0 & 0 & 0 & 0 & 0 \\
\hline Backfilled soil & 0 & 0 & 0.4 & 0.4 & 0.1 & 0.1 & 0 \\
\hline Hanford sands & 0 & 0 & 0.4 & 0.4 & 0.1 & 0.1 & 0 \\
\hline
\end{tabular}

The particle radius values assumed for Hanford sediments and backfilled soil are consistent with petrologic and particle size data obtained from laboratory measurements (Kaplan and Serne 1999). The radius of the glass is assumed to be 500 times larger on average. This is consistent with the expected sparse degree of glass fracturing in the waste package based on prior experience with high-level waste glasses (Farnsworth et al. 1985; Peters and Slate 1981). Fracturing is expected to increase the glass surface area a maximum of 10 times over its geometric surface area. 
Table 2. Particle Radius (m) of Solid Species in Material Zones

\begin{tabular}{||l|l|l|l|l|l|c|}
\hline & $\begin{array}{c}\text { ILAW } \\
\text { Glass }\end{array}$ & 304L SS & Quartz & Albite & $\begin{array}{c}\text { K- } \\
\text { Feldspar }\end{array}$ & Illite \\
\hline Waste package (old) & $5.00 \mathrm{E}-02$ & $5.00 \mathrm{E}-02$ & 0 & 0 & 0 & 0 \\
\hline Waste package (new) & $5.00 \mathrm{E}-02$ & $5.00 \mathrm{E}-02$ & 0 & 0 & 0 & 0 \\
\hline Container (old) & $5.00 \mathrm{E}-02$ & $5.00 \mathrm{E}-02$ & 0 & 0 & 0 & 0 \\
\hline Container (new) & $5.00 \mathrm{E}-02$ & $5.00 \mathrm{E}-02$ & 0 & 0 & 0 & 0 \\
\hline Backfilled soil & 0 & 0 & $1.00 \mathrm{E}-04$ & $1.00 \mathrm{E}-04$ & $1.00 \mathrm{E}-04$ & $5.00 \mathrm{E}-06$ \\
\hline Hanford sands & 0 & 0 & $1.00 \mathrm{E}-04$ & $1.00 \mathrm{E}-04$ & $1.00 \mathrm{E}-04$ & $5.00 \mathrm{E}-06$ \\
\hline
\end{tabular}

\subsubsection{Computational Grid}

For the 1-D simulations of both the old and new trench designs, the computational grid had a vertical resolution of $5 \mathrm{~cm}$, determined by grid sensitivity tests (Bacon and McGrail 2001). The time step used in the calculations was calculated automatically by the code given a convergence criterion of $1 \times 10^{-6}$. This ensures that predicted values of aqueous species concentrations and mineral volumes are accurate between iterations for a given time step. If this cannot be achieved within a certain number of iterations, the time step is automatically reduced.

\subsubsection{Material Hydraulic Properties}

The hydraulic properties for each lithographic unit in the simulation were defined as a part of the nearfield hydraulics data package (Meyer and Serne 1999) or the far-field hydraulic properties data package (Khaleel 1999). These data are provided in Table 3.

Table 3. Material Hydraulic Properties Used in Simulations

\begin{tabular}{|c|c|c|c|c|c|c|c|}
\hline Material & $\begin{array}{l}\text { Particle } \\
\text { Density } \\
\left(\mathrm{g} / \mathrm{cm}^{3}\right)\end{array}$ & $\begin{array}{c}\text { Bulk } \\
\text { Density } \\
\left(\mathrm{g} / \mathrm{cm}^{3}\right)\end{array}$ & $\begin{array}{c}\text { Saturated } \\
\text { Water } \\
\text { Content }\end{array}$ & $\begin{array}{c}\text { Residual } \\
\text { Water } \\
\text { Content }\end{array}$ & $\begin{array}{c}\text { van } \\
\text { Genuchten } \\
\alpha \\
\left(\mathrm{cm}^{-1}\right) \\
\end{array}$ & 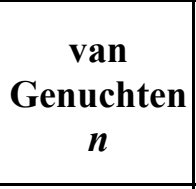 & $\begin{array}{c}\text { Saturated } \\
\text { Hydraulic } \\
\text { Conductivity } \\
(\mathrm{cm} / \mathrm{s}) \\
\end{array}$ \\
\hline Glass waste & 2.68 & 2.63 & 0.020 & 0.00 & 0.200 & 3.00 & 0.01 \\
\hline Container & 2.68 & 2.63 & 0.020 & 0.00 & 0.200 & 3.00 & 0.01 \\
\hline Backfill & 2.76 & 1.89 & 0.316 & 0.049 & 0.035 & 1.72 & $1.91 \times 10^{-3}$ \\
\hline Hanford sand & 2.74 & 1.71 & 0.375 & 0.041 & 0.055 & 1.77 & $2.88 \times 10^{-3}$ \\
\hline
\end{tabular}

\subsubsection{Hydraulic Initial Conditions}

Initial hydraulic conditions for each lithographic unit include the following parameters:

- water content

- water flux

- dissolved gas content of aqueous phase

- gas pressure 
- relative humidity of gas phase

- temperature.

The initial conditions were calculated by assuming a steady-state water flux at the upper boundary, which results in a steady-state water content distribution consistent with the hydraulic properties defined for each material. A wide spectrum of water flux rates, ranging from 0.1 to $50 \mathrm{~mm} / \mathrm{yr}$, was used for different sensitivity cases. A constant subsurface temperature equal to the average ambient temperature of $15^{\circ} \mathrm{C}$ was assumed. The dissolved gas content of the aqueous phase was assumed to be negligible with respect to flow. The relative humidity of the gas phase was assumed to be $100 \%$.

\subsubsection{Hydraulic Boundary Conditions}

The following data are needed as a function of time and space along each boundary:

- water flux

- dissolved gas content of aqueous phase

- gas pressure

- relative humidity of gas phase

- temperature.

The upper boundary is just beneath the engineered barrier system (EBS) and was assigned a specified flux. A wide spectrum of water flux rates, ranging from 0.1 to $50 \mathrm{~mm} / \mathrm{yr}$, was used for different sensitivity cases. The ambient recharge rates, 0.9 or $4.2 \mathrm{~mm} / \mathrm{yr}$, were determined as a part of the recharge data package (Fayer et al. 1999). The lowest recharge rate of $0.1 \mathrm{~mm} / \mathrm{yr}$ represents a perfectly working EBS. The highest recharge rate $(50 \mathrm{~mm} / \mathrm{yr})$ represents failure of the EBS with irrigation occurring above the disposal site.

The lower boundary is $15 \mathrm{~m}$ below the EBS. For hydraulic conditions at this lower boundary, free drainage under gravity is assumed. For 2-D simulations, the side boundaries are placed at axes of symmetry so that they can be assumed to be no-flow boundaries.

A constant subsurface temperature equal to the average ambient temperature of $15^{\circ} \mathrm{C}$ was assumed. The dissolved gas content of the aqueous phase was assumed to be negligible with respect to flow. The relative humidity of the gas phase was assumed to be $100 \%$.

\subsubsection{Solute Transport Coefficients}

For each gaseous and aqueous species, the following data are needed:

- aqueous diffusion coefficient $\left(\mathrm{m}^{2} \mathrm{~s}^{-1}\right)$

- gas diffusion coefficient $\left(\mathrm{m}^{2} \mathrm{~s}^{-1}\right)$ or an assumption that the gas partial pressure is fixed.

The aqueous diffusion coefficients were assumed to be $5 \times 10^{-9} \mathrm{~m}^{2} / \mathrm{s}$ for all aqueous species (Mann et al. 1998). The gas partial pressure for $\mathrm{CO}_{2}$ and $\mathrm{O}_{2}$ were fixed at atmospheric values of $3 \times 10^{-4} \mathrm{~atm}$ and $2.1 \times 10^{-1}$ atm, respectively. 


\subsection{Chemistry Input}

\subsubsection{Aqueous Species}

Aqueous species are the cations, anions, or neutral complexes present in the aqueous phase. For each aqueous species, the following data are needed:

- molecular weight

- charge

- hard core diameter

- number of elements in aqueous species

- $\quad$ stoichiometric coefficient of each element.

The aqueous species listed in Table 4 were identified by simulating the dissolution of LAWABP1 glass (along with a trace amount of calcite) in deionized water at $15^{\circ} \mathrm{C}$ with the EQ3/6 code package (Wolery and Daveler 1992). All data were obtained from the EQ3/6 data0.com.R8 database (Daveler and Wolery 1992). These simulations were not intended to be representative of disposal system conditions. The intent was only to make use of the EQ3/6 software to extract from the large thermodynamic database a subset of aqueous (and solid) species that was relevant for ILAW simulations. Because LAWABP1 glass contains all of the elements that are expected to be part of the final ILAW product produced by the vitrification contractor, the list of aqueous species given in Table 4 is expected to be reasonably complete.

\subsubsection{Gas Species}

Gas species are compounds such as $\mathrm{CO}_{2}$ and $\mathrm{O}_{2}$ that make up the air phase in STORM simulations. For each gas species, the following data are needed:

- molecular weight

- number of elements in gaseous species

- $\quad$ stoichiometric coefficient of each element.

Only $\mathrm{CO}_{2}$ and $\mathrm{O}_{2}$ are expected to influence the chemical environment significantly in the near and far fields. 
Table 4. Key Aqueous Species Produced by the Dissolution of Calcite and LAWABP1 Glass Containing Trace Amounts of I, Tc, Se, U, and Pu in Deionized Water

\begin{tabular}{|c|c|c|}
\hline Species & Mol Wt & Hard Core Diameter \\
\hline $\mathrm{AlO}_{2}^{-}$ & 58.98 & 4.0 \\
\hline $\mathrm{B}(\mathrm{OH})_{3}(\mathrm{aq})$ & 61.83 & 3.0 \\
\hline $\mathrm{Ca}^{2+}$ & 40.08 & 6.0 \\
\hline $\mathrm{CO}_{2}(\mathrm{aq})$ & 44.01 & 3.0 \\
\hline $\mathrm{CO}_{3}^{2-}$ & 60.01 & 5.0 \\
\hline $\mathrm{CrO}_{4}^{2-}$ & 115.99 & 4.0 \\
\hline $\mathrm{Fe}(\mathrm{OH})_{3}(\mathrm{aq})$ & 106.87 & 3.0 \\
\hline $\mathrm{H}_{2} \mathrm{O}$ & 18.01 & -4.0 \\
\hline $\mathrm{H}^{+}$ & 1.01 & 9.0 \\
\hline $\mathrm{HCO}_{3}^{-}$ & 61.02 & 4.0 \\
\hline $\mathrm{HCrO}_{4}^{-}$ & 117.00 & 4.0 \\
\hline $\mathrm{HSiO}_{3}^{-}$ & 77.09 & 4.0 \\
\hline $\mathrm{IO}_{3}^{-}$ & 126.90 & 3.0 \\
\hline $\mathrm{K}^{+}$ & 39.10 & 3.0 \\
\hline $\mathrm{La}^{3+}$ & 138.91 & 9.0 \\
\hline $\mathrm{Mg}^{2+}$ & 24.31 & 8.0 \\
\hline $\mathrm{Na}^{+}$ & 22.99 & 4.0 \\
\hline $\mathrm{NaAlO}_{2}(\mathrm{aq})$ & 81.97 & 3.0 \\
\hline $\mathrm{NaB}(\mathrm{OH})_{4}(\mathrm{aq})$ & 101.83 & 3.0 \\
\hline $\mathrm{NaCO}_{3}^{-}$ & 83.00 & 4.0 \\
\hline $\mathrm{NaCl}(\mathrm{aq})$ & 58.44 & 3.0 \\
\hline $\mathrm{NaHCO}_{3}(\mathrm{aq})$ & 84.00 & 3.0 \\
\hline $\mathrm{NaHSiO}_{3}(\mathrm{aq})$ & 100.08 & 0.0 \\
\hline $\mathrm{NaOH}(\mathrm{aq})$ & 40.00 & 3.0 \\
\hline $\mathrm{Ni}++$ & 58.69 & 4.5 \\
\hline $\mathrm{O}_{2}(\mathrm{aq})$ & 32.00 & 3.0 \\
\hline $\mathrm{OH}^{-}$ & 17.01 & 3.0 \\
\hline $\mathrm{PuO}_{2}\left(\mathrm{CO}_{3}\right)_{3}{ }^{4-}$ & 456.03 & 4.0 \\
\hline $\mathrm{SeO}_{4}{ }^{2-}$ & 142.96 & 4.0 \\
\hline $\mathrm{SiO}_{2}(\mathrm{aq})$ & 60.08 & 3.0 \\
\hline $\mathrm{TcO}_{4}^{-}$ & 162.00 & 4.0 \\
\hline $\mathrm{Ti}(\mathrm{OH})_{4}(\mathrm{aq})$ & 115.91 & 3.0 \\
\hline $\mathrm{UO}_{2}\left(\mathrm{CO}_{3}\right)_{2}{ }^{2-}$ & 390.05 & 4.0 \\
\hline $\mathrm{UO}_{2}\left(\mathrm{CO}_{3}\right)_{3}{ }^{4-}$ & 450.06 & 4.0 \\
\hline $\mathrm{UO}_{2}(\mathrm{OH})_{2}(\mathrm{aq})$ & 304.04 & 3.0 \\
\hline $\mathrm{Zn}^{2+}$ & 65.39 & 6.0 \\
\hline $\mathrm{Zr}(\mathrm{OH})_{4}(\mathrm{aq})$ & 159.25 & 3.0 \\
\hline
\end{tabular}




\subsubsection{Solid Species}

For each solid species, the mass density $\left(\mathrm{g} \mathrm{cm}^{-3}\right)$ and the stoichiometric coefficient of each element are needed. The simulation results presented in the following sections will reference two different ILAW glass compositions, which are provided in Table 5 for reference.

The mass density of both glasses was assumed to be $2.68 \mathrm{~g} \mathrm{~cm}^{-3}$. The compositions of the materials making up the backfill and Hanford sand used in the simulations are listed in Table 6. The mass density is obtained by dividing the molecular weight by the molar volume of the compound.

Table 5. Composition (Mole Fraction) of ILAW Glasses Used in Simulations

\begin{tabular}{|l|l|l||}
\hline Element & LAWABP1 & \multicolumn{1}{|c|}{ HLP-31 } \\
\hline $\mathrm{Al}$ & $1.36 \times 10^{-1}$ & $5.06 \times 10^{-2}$ \\
\hline $\mathrm{B}$ & $1.84 \times 10^{-1}$ & $2.22 \times 10^{-1}$ \\
\hline $\mathrm{Ca}$ & ----- & $1.15 \times 10^{-4}$ \\
\hline $\mathrm{Cl}$ & $1.13 \times 10^{-2}$ & $5.82 \times 10^{-3}$ \\
\hline $\mathrm{Cr}$ & $1.82 \times 10^{-4}$ & $7.64 \times 10^{-4}$ \\
\hline $\mathrm{F}$ & $1.46 \times 10^{-3}$ & $3.39 \times 10^{-4}$ \\
\hline $\mathrm{Fe}$ & $2.16 \times 10^{-2}$ & $2.71 \times 10^{-2}$ \\
\hline $\mathrm{I}$ & $1.54 \times 10^{-7}$ & $1.66 \times 10^{-7}$ \\
\hline $\mathrm{K}$ & $3.23 \times 10^{-2}$ & $6.44 \times 10^{-3}$ \\
\hline $\mathrm{La}$ & $8.48 \times 10^{-3}$ & ----- \\
\hline $\mathrm{Mg}$ & $1.71 \times 10^{-2}$ & $1.47 \times 10^{-2}$ \\
\hline $\mathrm{Na}$ & $4.46 \times 10^{-1}$ & $4.79 \times 10^{-1}$ \\
\hline $\mathrm{O}$ & 1.87 & 1.87 \\
\hline $\mathrm{P}$ & $7.79 \times 10^{-4}$ & $5.45 \times 10^{-4}$ \\
\hline $\mathrm{Pu}$ & $3.52 \times 10^{-8}$ & $3.78 \times 10^{-8}$ \\
\hline $\mathrm{Tc}$ & $6.59 \times 10^{-7}$ & $7.58 \times 10^{-7}$ \\
\hline $\mathrm{S}$ & $8.63 \times 10^{-4}$ & $6.44 \times 10^{-4}$ \\
\hline $\mathrm{Se}$ & $1.77 \times 10^{-8}$ & $1.90 \times 10^{-8}$ \\
\hline $\mathrm{Si}$ & $4.82 \times 10^{-1}$ & $5.58 \times 10^{-1}$ \\
\hline $\mathrm{Ti}$ & $2.15 \times 10^{-2}$ & $1.48 \times 10^{-2}$ \\
\hline $\mathrm{U}$ & $9.81 \times 10^{-5}$ & $1.05 \times 10^{-4}$ \\
\hline $\mathrm{Zn}$ & $2.20 \times 10^{-2}$ & $7.29 \times 10^{-3}$ \\
\hline $\mathrm{Zr}$ & $2.94 \times 10^{-2}$ & $4.82 \times 10^{-3}$ \\
\hline
\end{tabular}

Table 6. Composition of Native and Other Surrounding Materials Used in Simulations

\begin{tabular}{|l|l|c|c||}
\hline \multicolumn{1}{|c|}{ Species } & \multicolumn{1}{c|}{ Formula } & Mol Wt & Molar Volume \\
\hline Albite & $\mathrm{NaAlSi}_{3} \mathrm{O}_{8}$ & 262.2 & 100.4 \\
\hline Illite & $\mathrm{K}_{0.6} \mathrm{Mg}_{0.25} \mathrm{Al}_{1.8} \mathrm{Al}_{0.5} \mathrm{Si}_{3.5} \mathrm{O}_{10}(\mathrm{OH})_{2}$ & 383.9 & 500.0 \\
\hline K-Feldspar & $\mathrm{KAlSi}_{3} \mathrm{O}_{8}$ & 278.3 & 108.8 \\
\hline Quartz & $\mathrm{SiO}_{2}$ & 60.0 & 22.6 \\
\hline
\end{tabular}


Secondary phases are solids that precipitate from a supersaturated aqueous solution. A list of potential secondary phases that form from long-term weathering experiments with LAWABP1 glass and from modeling the solution chemistry observed in experiments with the EQ3/6 code is provided by McGrail et al. (2001). They eliminated a large number of phases from consideration because 1) formation of the phase is kinetically prohibited at the disposal system temperature of $15^{\circ} \mathrm{C}, 2$ ) selection of the phase would violate the Gibbs phase rule, 3) simulations show that allowing the phase to form is inconsistent with a large body of laboratory test data with borosilicate glasses, and 4) the phase is unstable over the range of chemical environments expected for the ILAW disposal system. The final phase assemblage used in STORM simulations (see Table 7) was further constrained because preliminary runs showed that the phase never formed or formed in such small amounts that the effects were insignificant. The composition of the secondary minerals used in the simulations is listed in Table 7. The mass density is obtained by dividing the molecular weight by the molar volume of the solid.

Table 7. Composition of Secondary Minerals Used in Simulations

\begin{tabular}{|l|l|c|c||}
\hline \multicolumn{1}{|c|}{ Species } & \multicolumn{1}{|c|}{ Formula } & Mol Wt & Molar Volume \\
\hline Amorphous silica & $\mathrm{SiO}_{2}$ & 60.0 & 29.0 \\
\hline Analcime & $\mathrm{Na}_{0.96} \mathrm{Al}_{0.96} \mathrm{Si}_{2.04} \mathrm{O}_{6}$ & 201.2 & 89.1 \\
\hline Anatase & $\mathrm{TiO}_{2}$ & 79.8 & 18.8 \\
\hline Baddeleyite & $\mathrm{ZrO}_{2}$ & 123.2 & 21.9 \\
\hline Gibbsite & $\mathrm{Al}(\mathrm{OH})_{3}$ & 78.0 & 31.9 \\
\hline Goethite & $\mathrm{FeOOH}$ & 88.8 & 20.8 \\
\hline Herschelite & $\mathrm{Na}_{1.62} \mathrm{~K}_{0.5} \mathrm{Al}_{2.26} \mathrm{Si}_{4} \mathrm{O}_{12.45} \cdot 6 \mathrm{H}_{2} \mathrm{O}$ & 537.4 & 29.9 \\
\hline La(OH)3 & ${\mathrm{La}(\mathrm{OH})_{3}}_{3}$ & 189.9 & 54.5 \\
\hline Nontronite- $\mathrm{Na}$ & $\mathrm{Na}_{0.33} \mathrm{Fe}_{2} \mathrm{Al}_{0.33} \mathrm{Si}_{3.67} \mathrm{O}_{11} \cdot \mathrm{H}_{2} \mathrm{O}$ & 425.2 & 184.8 \\
\hline PuO2 & $\mathrm{PuO}_{2}$ & 276.0 & 23.8 \\
\hline Sepiolite & $\mathrm{Mg}_{4} \mathrm{Si}_{6} \mathrm{O}_{15}\left(\mathrm{OH}_{2}: 6 \mathrm{H}_{2} \mathrm{O}\right.$ & 647.8 & 285.6 \\
\hline Soddyite & $\left(\mathrm{UO}_{2}\right) 2\left(\mathrm{SiO}_{4}\right): 2 \mathrm{H}_{2} \mathrm{O}$ & 668.1 & 131.2 \\
\hline Weeksite & $\mathrm{K}_{2}\left(\mathrm{UO}_{2}\right)_{2} \mathrm{Si}_{6} \mathrm{O}_{15} \cdot 4 \mathrm{H}_{2} \mathrm{O}$ & 1098.8 & 500.0 \\
\hline $\mathrm{Zn}(\mathrm{OH}) 2$ & ${\mathrm{Zn}(\mathrm{OH})_{2}}$ & 99.4 & 500.0 \\
\hline
\end{tabular}

\subsubsection{Equilibrium Reactions}

For each equilibrium reaction, the stoichiometric coefficient of each aqueous species in each reaction and the equilibrium constant at a temperature of $15^{\circ} \mathrm{C}$ are needed. The equilibrium reactions in Table 8 were identified by simulating the dissolution of LAWABP1 glass in deionized water at $15^{\circ} \mathrm{C}$ with the EQ3/6 code (Wolery and Daveler 1992) and the data0.com.R8 database (Daveler and Wolery 1992; Wolery and Daveler 1992). It was possible to exclude a significant number of secondary aqueous species from the simulations because their concentrations were extremely small over the range of chemical conditions anticipated for the ILAW disposal system. 
Table 8. Equilibrium Reactions from Dissolution of LAWABP1 Glass at $15^{\circ} \mathrm{C}$

\begin{tabular}{||l|l|l||}
\hline \multicolumn{1}{|c|}{ Reaction } & Log K & \multicolumn{1}{c||}{ Source } \\
\hline $\mathrm{CO}_{2}(\mathrm{aq})+\mathrm{H}_{2} \mathrm{O} \Leftrightarrow \mathrm{H}^{+}+\mathrm{HCO}_{3}^{-}$ & -6.417 & Shock et al. (1989) \\
\hline $\mathrm{CO}_{3}{ }^{2-}+\mathrm{H}^{+} \Leftrightarrow \mathrm{HCO}_{3}{ }^{-}$ & 10.429 & Shock and Helgeson (1988) \\
\hline $\mathrm{HCrO}_{4}{ }^{-} \Leftrightarrow \mathrm{CrO}_{4}{ }^{2-}+\mathrm{H}^{+}$ & -6.491 & Shock and Helgeson (1988) \\
\hline $\mathrm{HSiO}_{3}{ }^{-}+\mathrm{H}^{+} \Leftrightarrow \mathrm{SiO}_{2}(\mathrm{aq})+\mathrm{H}_{2} \mathrm{O}$ & 10.101 & Sverjensky and Sahai (1996) \\
\hline $\mathrm{OH}^{-}+\mathrm{H}^{+} \Leftrightarrow \mathrm{H}_{2} \mathrm{O}$ & 14.344 & Shock and Helgeson (1988) \\
\hline $\mathrm{UO}_{2}\left(\mathrm{CO}_{3}\right)_{3}{ }^{4-}+2 \mathrm{H}_{2} \mathrm{O}+\mathrm{H}^{+} \Leftrightarrow 3 \mathrm{HCO}_{3}{ }^{-}+\mathrm{UO}_{2}(\mathrm{OH}) 2(\mathrm{aq})$ & -0.970 & Grenthe et al. (1992) \\
\hline $\mathrm{UO}_{2}\left(\mathrm{CO}_{3}\right)_{2}{ }^{2-}+2 \mathrm{H}_{2} \mathrm{O} \Leftrightarrow 2 \mathrm{HCO}_{3}{ }^{-}+\mathrm{UO}_{2}(\mathrm{OH}) 2(\mathrm{aq})$ & -6.520 & Grenthe et al. (1992) \\
\hline
\end{tabular}

\subsubsection{Kinetic Reactions}

For each kinetic reaction, the following data are needed:

- mass action law type: full, reduced, or glass

- stoichiometric coefficient of aqueous species in each reaction

- equilibrium constant at a temperature of $15^{\circ} \mathrm{C}$

- rate constant of reaction.

A full mass-action law type will be used for each solid phase except the waste glass. A special massaction law type implemented in the STORM code that will be used for the glass is discussed in the following section.

Compilations of kinetic rate constants, equivalent to thermodynamic databases for important mineral phases, are not available. Also, the available mineral dissolution/precipitation kinetics data are much more limited than the thermodynamic data. Consequently, sufficiently large rate constants are used to approximate equilibrium conditions, i.e., to ensure that the phase will precipitate rapidly if the local chemical environment at a grid node is saturated with respect to the particular phase. This has an additional advantage in that uncertainty in the exact value of a particular rate constant will have little impact on the calculations.

\section{Glass Rate Law}

The corrosion reaction for LAWABP1 glass used in the waste form release calculations is

$$
\begin{aligned}
\text { LAW } & \text { BP } 1+4.42 \times 10^{-1} \mathrm{H}^{+}+1.89 \times 10^{-1} \mathrm{H}_{2} \mathrm{O} \rightarrow 1.36 \times 10^{-1} \mathrm{AlO}_{2}^{-} \\
+ & 1.84 \times 10^{-1} \mathrm{~B}(\mathrm{OH})_{3}(\mathrm{aq})+1.13 \times 10^{-2} \mathrm{Cl}^{-}+1.82 \times 10^{-4} \mathrm{CrO}_{4}^{2-} \\
& +1.46 \times 10^{-3} \mathrm{~F}^{-}+2.16 \times 10^{-2} \mathrm{Fe}(\mathrm{OH})_{3}(\mathrm{aq})+1.54 \times 10^{-7} \mathrm{IO}_{3}^{-} \\
& +3.23 \times 10^{-2} \mathrm{~K}^{+}+8.48 \times 10^{-3} \mathrm{La}^{3+}+1.71 \times 10^{-2} \mathrm{Mg}^{2+}+4.46 \times 10^{-1} \mathrm{Na}^{+} \\
& +7.79 \times 10^{-4} \mathrm{HPO}_{4}^{2-}+3.52 \times 10^{-8} \mathrm{PuO}_{2}\left(\mathrm{CO}_{3}\right)_{3}^{4-}+8.63 \times 10^{-4} \mathrm{SO}_{4}^{2-} \\
& +1.77 \times 10^{-8} \mathrm{SeO}_{4}^{2-}+4.82 \times 10^{-1} \mathrm{SiO}_{2}(\mathrm{aq})+6.59 \times 10^{-7} \mathrm{TcO}_{4}^{-} \\
& +2.15 \times 10^{-2} \mathrm{Ti}(\mathrm{OH})_{4}(\mathrm{aq})+9.81 \times 10^{-7} \mathrm{UO}_{2}(\mathrm{OH})_{2}(\mathrm{aq}) \\
+ & 2.20 \times 10^{-2} \mathrm{Zn}^{2+}+2.94 \times 10^{-2} \mathrm{Zr}(\mathrm{OH})_{4}(\mathrm{aq})
\end{aligned}
$$


Similarly, the corrosion reaction for HLP-31 glass is

$$
\begin{aligned}
\mathrm{HLP}- & 31 \rightarrow 6.84 \times 10^{-1} \mathrm{OH}^{-}+5.06 \times 10^{-2} \mathrm{Al}^{3+}+2.22 \times 10^{-1} \mathrm{~B}(\mathrm{OH})_{3}(\mathrm{aq}) \\
+ & 1.15 \times 10^{-4} \mathrm{Ca}^{2+}+7.64 \times 10^{-4} \mathrm{CrO}_{4}^{2-}+2.72 \times 10^{-2} \mathrm{Fe}(\mathrm{OH})_{3}(\mathrm{aq}) \\
+ & 1.66 \times 10^{-7} \mathrm{IO}_{3}^{-}+6.44 \times 10^{-3} \mathrm{~K}^{+}+1.47 \times 10^{-2} \mathrm{Mg}^{2+}+4.78 \times 10^{-1} \mathrm{Na}^{+} \\
+ & 3.78 \times 10^{-8} \mathrm{PuO}_{2}\left(\mathrm{CO}_{3}\right)_{3}^{4-}+1.90 \times 10^{-8} \mathrm{SeO}_{4}^{2-}+5.58 \times 10^{-1} \mathrm{SiO}_{2}(\mathrm{aq}) \\
& +7.58 \times 10^{-7} \mathrm{TcO}_{4}^{-}+1.48 \times 10^{-2} \mathrm{Ti}(\mathrm{OH})_{4}(\mathrm{aq})+1.05 \times 10^{-4} \mathrm{UO}_{2}(\mathrm{OH})_{2}(\mathrm{aq}) \\
& +7.29 \times 10^{-3} \mathrm{Zn}^{2+}+4.82 \times 10^{-3} \mathrm{Zr}(\mathrm{OH})_{4}(\mathrm{aq})
\end{aligned}
$$

The stoichiometric coefficients for the radionuclides $\mathrm{I}, \mathrm{Pu}, \mathrm{Se}$, and $\mathrm{Tc}$ are based on the average package concentration from the Immobilized Low Activity Tank Waste Inventory Data Package (Wootan 1999). For a dissolution reaction involving glass, parameters associated with the following kinetic rate law are needed:

$$
r_{g}=\vec{k} a_{\mathrm{H}^{+}}^{-\eta} e \frac{-E_{a}}{\mathrm{RT}}\left[1-\left(\frac{Q}{K_{g}}\right)^{\sigma}\right]
$$

where

$$
\begin{aligned}
r_{g} & =\text { dissolution rate, } \mathrm{g} \mathrm{m}^{-2} \mathrm{~d}^{-1} \\
\vec{k} & =\text { intrinsic rate constant, } \mathrm{g} \mathrm{m}^{-2} \mathrm{~d}^{-1} \\
a_{\mathrm{H}^{+}} & =\text {hydrogen ion activity }(\text { variable to be calculated by STORM) } \\
E_{a} & =\text { activation energy, } \mathrm{kJ} / \mathrm{mol} \\
R & =\text { gas constant, } \mathrm{kJ} /(\mathrm{mol} \cdot \mathrm{K}) \\
T & =\text { temperature, } \mathrm{K}\left(\text { assumed constant at } 15^{\circ} \mathrm{C}\right) \\
Q & =\text { ion activity product glass }(\text { variable to be calculated by STORM) } \\
K_{g} & =\text { pseudoequilibrium constant } \\
\eta & =\text { pH power law coefficient } \\
\sigma & =\text { Temkin coefficient }(\sigma=1 \text { assumed }) .
\end{aligned}
$$

Equation (3) is an approximation for glass because glass is metastable and the reaction proceeds one way (i.e., glass dissolves). The unknown parameters in Equation (1) $\left(\vec{k}, E_{a}, K_{g}\right.$, and $\left.\eta\right)$ have been determined for LAWABP1 and HLP-31 (McGrail et al. 2001) glasses. These values are given in Table 9. The values given by McGrail et al. (2001) for LAWABP1 glass differ slightly from the values given in Table 9, which were based on an earlier revision of the Waste Form Release Data Package (McGrail et al. 2000). Additional data obtained between the times when the STORM calculations were performed and when the data package was updated changed the parameters slightly.

Test results with HLP-31 glass showed that, unlike most silicate glasses, the dissolution rate did not diminish with increasing concentration of silicon in solution. Consequently, no pseudoequilibrium phase or $K_{g}$ was assigned to this glass. In addition, test results with LAWABP1 glass (and most other ILAW glasses) show that it is susceptible to a secondary reaction mechanism, alkali ion exchange. This reaction results in the selective extraction of sodium via: 


$$
\text { LAWABP1-Na }+\mathrm{H}^{+} \rightarrow \mathrm{LAWABP} 1-\mathrm{H}+\mathrm{Na}^{+}
$$

where LAWABP1-Na represents the unreacted glass containing sodium, and LAWABP1-H represents a hydrated glass where the sodium has been replaced with an equimolar amount of hydrogen. The rate of this reaction has been determined from single-pass flow-through experiments by McGrail et al. (2001). The rate constant is $2.5 \times 10^{6} \mathrm{~g} \mathrm{~m}^{-2} \mathrm{~s}^{-1}$ (again, slightly different from the value given in Table 9). STORM keeps track of the amount of hydrated glass formed via Reaction (4) and then allows it to dissolve according to the same kinetic rate law (Reaction 3) as the parent glass. The ion-exchange rate for HLP-31 glass was set at zero, consistent with the results reported by McGrail et al. (2001).

Table 9. Summary of Kinetic Rate Parameters Used for Glasses

\begin{tabular}{|l|l|c|c|l||}
\hline \hline Parameter & \multicolumn{1}{|c|}{ Meaning } & LAWABP1 & HLP-31 & \multicolumn{1}{c|}{ Comment } \\
\hline \hline$\vec{k}$ & Intrinsic rate constant & $3.5 \times 10^{5} \mathrm{~g} \mathrm{~m}^{-2} \mathrm{~d}^{-1}$ & $3 \times 10^{6} \mathrm{~g} \mathrm{~m}^{-2} \mathrm{~d}^{-1}$ & $\begin{array}{l}\text { HLP-31 assumed } \\
\text { roughly 10 times faster } \\
\text { than LAWABP1 }\end{array}$ \\
\hline$K_{g}$ & $\begin{array}{l}\text { Apparent } \\
\text { equilibrium constant } \\
\text { for glass based on } \\
\text { activity of } \mathrm{SiO}_{2}(\mathrm{aq})\end{array}$ & $10^{-2.9}$ & $\mathrm{~N} / \mathrm{A}$ & $\begin{array}{l}\text { HLP-31 glass } \\
\text { dissolution rate did not } \\
\text { change as a function of } \\
\text { SiO }(\text { aq })\end{array}$ \\
\hline$\eta$ & $\begin{array}{l}\text { pH power law } \\
\text { coefficient }\end{array}$ & 0.5 & 0.5 & $\begin{array}{l}\text { HLP-31 value assumed } \\
\text { same as LAWABP1 }\end{array}$ \\
\hline$E_{a}$ & $\begin{array}{l}\text { Activation energy of } \\
\text { glass dissolution } \\
\text { reaction }\end{array}$ & $75 \mathrm{~kJ} / \mathrm{mol}$ & $75 \mathrm{~kJ} / \mathrm{mol}$ & $\begin{array}{l}\text { HLP-31 value assumed } \\
\text { same as LAWABP1 }\end{array}$ \\
\hline$\sigma$ & Temkin coefficient & \multicolumn{1}{|c|}{1} & 1 & Assigned constant \\
\hline$r_{x}$ & $\begin{array}{l}\text { Sodium ion } \\
\text { exchange rate }\end{array}$ & $3.5 \times 10^{-6} \mathrm{~mol} \mathrm{~m}^{-2} \mathrm{~d}^{-1}$ & 0 & $\begin{array}{l}\text { No detectable ion } \\
\text { exchange for HLP-31 }\end{array}$ \\
\hline \hline
\end{tabular}

\subsubsection{Effect of Steel Containers}

The following is the corrosion reaction for the $304 \mathrm{~L}$ stainless steel containers into which the molten LAW is poured (Cloke et al. 1997):

$$
\begin{aligned}
\text { Steel }+ & 2.9262 \times 10^{-2} \mathrm{H}^{+}+1.7618 \mathrm{H}_{2} \mathrm{O}+3.4169 \times 10^{-1} \mathrm{O}_{2}(\mathrm{aq}) \rightarrow \\
& 3.4667 \times 10^{-3} \mathrm{HCO}_{3}^{-}+3.4701 \times 10^{-1} \mathrm{CrO}_{4}^{2-}+1.1828 \mathrm{Fe}(\mathrm{OH})_{3}(\mathrm{aq}) \\
+ & 3.5167 \times 10^{-2} \mathrm{Mn}^{2+}+9.9093 \times 10^{-3} \mathrm{NO}_{3}^{-}+1.8583 \times 10^{-1} \mathrm{Ni}^{2+} \\
+ & 8.8004 \times 10^{-4} \mathrm{HPO}_{4}^{2-}+5.2008 \times 10^{-4} \mathrm{SO}_{4}^{2-}+1.7325 \times 10^{-2} \mathrm{SiO}_{2}(\mathrm{aq})
\end{aligned}
$$


The 304L stainless steel corrosion rate was assumed to be a constant $6.87 \times 10^{-14} \mathrm{~mol} \mathrm{~cm}^{-2} \mathrm{~s}^{-1}$ (Cloke et al. 1997). Thus, the steel corrosion rate is not affected by changes in $\mathrm{pH}$ or water chemistry. By assuming this rate, the stainless steel corrodes away entirely within 1,000 years. Stainless steel was included in the upper and lower nodes of each glass waste package layer.

\subsubsection{Secondary Phase Equilibrium Constants}

McGrail et al. (2001) describe the methods used to develop a solubility product for the key secondary phases identified from laboratory testing and from simulations with the EQ3/6 code. For convenience, the $\log \mathrm{K}$ they derived for each secondary phase given in Table 7 is reproduced in Table 10. For the secondary phases, where a $\log \mathrm{K}$ was not available or could not be estimated, the reaction was not included in the STORM simulations.

Table 10. Secondary Phase Reaction Network for LAWABP1 Glass

\begin{tabular}{||l|c||}
\hline \multicolumn{1}{|c||}{ Reaction } & $\begin{array}{c}\text { Log K } \\
(\mathbf{1 5}\end{array}$ \\
\hline $\mathrm{Al}(\mathrm{OH})_{3}(\mathrm{am}) \Leftrightarrow \mathrm{AlO}_{2}{ }^{-}+\mathrm{H}^{+}+\mathrm{H}_{2} \mathrm{O}$ & -13.10 \\
\hline Analcime $\Leftrightarrow 0.96 \mathrm{AlO}_{2}{ }^{-}+0.96 \mathrm{Na}^{+}+2.04 \mathrm{SiO}_{2}(\mathrm{aq})$ & -9.86 \\
\hline Anatase $+2 \mathrm{H}_{2} \mathrm{O} \Leftrightarrow \mathrm{Ti}(\mathrm{OH})_{4}(\mathrm{aq})$ & -6.64 \\
\hline Baddeleyite $+2 \mathrm{H}_{2} \mathrm{O} \Leftrightarrow \mathrm{Zr}(\mathrm{OH})_{4}(\mathrm{aq})$ & -9.29 \\
\hline Goethite $+\mathrm{H}_{2} \mathrm{O} \Leftrightarrow \mathrm{Fe}(\mathrm{OH})_{3}(\mathrm{aq})$ & -11.09 \\
\hline Herschelite $\Leftrightarrow 1.62 \mathrm{Na}^{+}(\mathrm{aq})+0.50 \mathrm{~K}^{+}(\mathrm{aq})+2.26 \mathrm{AlO}_{2}{ }^{-}+4 \mathrm{SiO}_{2}(\mathrm{aq})+0.14 \mathrm{H}^{+}+5.93 \mathrm{H}_{2} \mathrm{O}$ & -40.94 \\
\hline $\mathrm{La}(\mathrm{OH})_{3}(\mathrm{am})+3 \mathrm{H}^{+} \Leftrightarrow 3 \mathrm{H}_{2} \mathrm{O}+\mathrm{La}^{3+}$ & 22.55 \\
\hline Nontronite- $\mathrm{Na}^{+}+2 \mathrm{H}_{2} \mathrm{O} \Leftrightarrow 0.330 \mathrm{AlO}_{2}{ }^{-}+2 \mathrm{Fe}(\mathrm{OH})_{3}(\mathrm{aq})+0.330 \mathrm{Na}^{+}+3.67 \mathrm{SiO}_{2}(\mathrm{aq})$ & -43.33 \\
\hline $\mathrm{PuO}{ }_{2}+\mathrm{HCO}{ }_{3}^{-}+0.5 \mathrm{O}_{2}(\mathrm{aq}) \Leftrightarrow \mathrm{PuO}_{2}\left(\mathrm{CO}_{3}\right)_{3}{ }^{4-}+\mathrm{H}_{2} \mathrm{O}+\mathrm{H}^{+}$ & -15.92 \\
\hline $\mathrm{Sepiolite}+8 \mathrm{H}^{+} \Leftrightarrow 4 \mathrm{Mg}^{2+}+6 \mathrm{SiO}_{2}(\mathrm{aq})+11 \mathrm{H}_{2} \mathrm{O}$ & 31.29 \\
\hline $\mathrm{SiO}{ }_{2}(\mathrm{am}) \Leftrightarrow \mathrm{SiO}_{2}(\mathrm{aq})$ & -2.85 \\
\hline Weeksite $+2 \mathrm{H}^{+} \Leftrightarrow 2 \mathrm{~K}^{+}+2 \mathrm{UO}_{2}\left(\mathrm{OH}_{2}(\mathrm{aq})+6 \mathrm{SiO}_{2}(\mathrm{aq})+3 \mathrm{H}_{2} \mathrm{O}\right.$ & -5.25 \\
\hline Soddyite $\Leftrightarrow 2 \mathrm{UO}_{2}(\mathrm{OH})_{2}(\mathrm{aq})+\mathrm{SiO}_{2}(\mathrm{aq})$ & -20.24 \\
\hline Theophrasite $+2 \mathrm{H}^{+} \Leftrightarrow 2 \mathrm{H}_{2} \mathrm{O}+\mathrm{Ni}^{2+}$ & 13.33 \\
\hline $\mathrm{Zn}(\mathrm{OH})_{2}(\mathrm{am})+2 \mathrm{H}^{+} \Leftrightarrow 2 \mathrm{H}_{2} \mathrm{O}+\mathrm{Zn}^{2+}$ & 14.44 \\
\hline \hline
\end{tabular}

\subsubsection{Initial and Boundary Conditions}

For each specified gas species concentration, the partial pressure of gaseous species data are needed. The gas partial pressure for $\mathrm{CO}_{2}$ and $\mathrm{O}_{2}$ were fixed at atmospheric values of $3 \times 10^{-4}$ and $2.1 \times 10^{-1} \mathrm{~atm}$, respectively. For each specified aqueous species, the specified total concentration and stoichiometric coefficient of each aqueous species data are needed. Aqueous species concentrations at the upper boundary and for initial conditions were specified as a part of the near-field geochemistry data package (Kaplan and Serne 1999) and are given in Table 11. 
Table 11. Initial Aqueous Concentrations Used in Simulations

\begin{tabular}{|c|c|}
\hline Species & $\begin{array}{c}\text { Initial } \\
\begin{array}{c}\text { Concentration } \\
\left(\mathrm{mol} \mathrm{kg}^{-1}\right)\end{array} \\
\end{array}$ \\
\hline $\mathrm{AlO}_{2}^{-}$ & $10^{-6}$ \\
\hline $\mathrm{B}(\mathrm{OH})_{3}(\mathrm{aq})$ & $10^{-10}$ \\
\hline $\mathrm{Ca}^{2+}$ & $10^{-7}$ \\
\hline $\mathrm{Cr}$ (total) & $10^{-10}$ \\
\hline $\mathrm{Fe}(\mathrm{OH})_{3}(\mathrm{aq})$ & $10^{-10}$ \\
\hline $\mathrm{H}_{2} \mathrm{O}$ & 1 \\
\hline $\mathrm{H}^{+}$ & $10^{-7}$ \\
\hline $\mathrm{IO}_{3}^{-}$ & $10^{-10}$ \\
\hline $\mathrm{K}^{+}$ & $10^{-6}$ \\
\hline $\mathrm{La}^{3+}$ & $10^{-10}$ \\
\hline $\mathrm{Mg}^{2+}$ & $10^{-10}$ \\
\hline $\mathrm{Na}^{+}$ & $10^{-6}$ \\
\hline $\mathrm{Ni}^{2+}$ & $10^{-10}$ \\
\hline $\mathrm{PuO}_{2}\left(\mathrm{CO}_{3}\right)_{3}{ }^{4-}$ & $10^{-10}$ \\
\hline $\mathrm{SeO}_{4}{ }^{2-}$ & $10^{-10}$ \\
\hline Si (total) & $10^{-5}$ \\
\hline $\mathrm{TcO}_{4}^{-}$ & $10^{-10}$ \\
\hline $\mathrm{Ti}(\mathrm{OH})_{4}(\mathrm{aq})$ & $10^{-10}$ \\
\hline $\mathrm{U}$ (total) & $10^{-10}$ \\
\hline $\mathrm{Zn}^{2+}$ & $10^{-10}$ \\
\hline $\mathrm{Zr}(\mathrm{OH})_{4}(\mathrm{aq})$ & $10^{-10}$ \\
\hline
\end{tabular}

For water flow, boundary conditions used were constant specified flux at the upper boundary and free drainage at the lower boundary. The reactive transport simulations boundary conditions were specified aqueous species concentrations at the upper boundary and no diffusion across the lower boundary. The contaminant flux across the lower boundary is therefore limited to advection:

$$
f=c \rho_{w} v
$$

where

$$
\begin{aligned}
& \left.c=\text { concentration }(\mathrm{mol} \mathrm{kg})^{-1}\right) \\
& \rho_{w}=\text { density of water }\left(\mathrm{kg} \mathrm{m}^{-3}\right) \\
& v=\text { specific discharge }\left(\mathrm{m} \mathrm{s}^{-1}\right)
\end{aligned}
$$




\subsection{Model Output}

The normalized flux to the vadose zone is calculated by summing the flux at each node across the bottom boundary of the model and normalizing the total flux according to the amount of each radionuclide in all the waste packages at the start of the simulation. The normalized flux across the lower boundary, $F$, in units of $\mathrm{ppm} / \mathrm{yr}$ was calculated:

$$
F=\frac{\sum_{i=1}^{N} f_{i} \Delta x_{i} \Delta y_{i}}{I_{j}}\left(3.1558 \times 10^{7} \mathrm{~s} \mathrm{yr}^{-1}\right)\left(1 \times 10^{6} \mathrm{ppm}\right)
$$

where

$f_{i} \quad=$ flux across the bottom of an individual grid block $\left(\mu\right.$ mole $\left.\mathrm{m}^{-2} \mathrm{~s}^{-1}\right)$

$\Delta x_{i} \Delta y_{i}=$ cross-sectional area of an individual grid block $\left(\mathrm{m}^{2}\right)$

$I_{j} \quad=$ inventory of $j$ th radionuclide in the waste packages $(\mu \mathrm{mol})$, where

$$
I_{j}=V_{w p}\left(1-\theta_{T}\right) V_{G} \rho_{G} \gamma_{j}
$$

where

$$
\begin{aligned}
V_{w p}= & \text { volume of the waste packages }\left(\mathrm{m}^{3}\right) \\
\theta_{T}= & \text { total porosity of the material representing the waste packages }(0.02) \\
V_{G}= & \text { fraction of glass in each waste package }(0.85) \\
\rho_{G}= & \text { molar density of LAWABP1 glass }\left(38776.1450 \text { moles } \mathrm{m}^{-3}\right) \\
\gamma_{j}= & \text { mole fraction of } j \text { th radionuclide in LAWABP1 glass (i.e., } 6.59 \times 10^{-1} \mu \text { moles Tc mole }{ }^{-1} \\
& \text { glass). }
\end{aligned}
$$

The volume of the waste packages, $V_{w p}$, was $5.6 \mathrm{~m}^{3}$ for the 1 -D old trench simulations and $6.9 \mathrm{~m}^{3}$ for the 1-D new trench simulations. For 1-D simulations, the cross-sectional area of the grid block was $1 \mathrm{~m}^{2}$. 


\subsection{Results}

Seven new 1-D simulations, labeled WF31 through WF37 following the numbering scheme from the 2001 ILAW PA, were run to test the sensitivity of model calculations to various assumptions (Table 12). Cases WFA and WF25 from the 2001 ILAW PA are included for comparison. Discussion of the results of these new simulations follows. Case WFA, the base case for the 2001 ILAW PA, did not include the effect of the stainless steel waste packages. Case WF25 is identical to the base case except that the stainless steel waste packages are included.

Table 12. List of 1-D Waste Form Sensitivity Cases

\begin{tabular}{|c|c|c|c|}
\hline Case $^{(a)}$ & Design & $\begin{array}{c}\text { Include Steel in Waste } \\
\text { Packages }\end{array}$ & $\begin{array}{c}\text { Water Infiltration Rate } \\
(\mathrm{mm} / \mathrm{yr})\end{array}$ \\
\hline WFA & Old design (4 x 1.4 m layers) & No & 4.2 \\
\hline WF25 & Old design (4 x 1.4 m layers) & Yes & 4.2 \\
\hline WF31 & New design $(3 \times 2.3$ m layers $)$ & Yes & 4.2 \\
\hline WF32 & New design $(3 \times 2.3$ m layers $)$ & Yes & 0.1 \\
\hline WF33 & New design $(3 \times 2.3$ m layers $)$ & Yes & 0.9 \\
\hline WF34 & New design $(3 \times 2.3$ m layers $)$ & Yes & 10 \\
\hline WF35 & New design $(3 \times 2.3$ m layers $)$ & Yes & 50 \\
\hline WF36 & $\begin{array}{l}\text { New design ( } 3 \times 2.3 \mathrm{~m} \text { layers }) \\
\text { top/bottom layers only }\end{array}$ & Yes & 0.9 \\
\hline WF37 & $\begin{array}{l}\text { New design ( } 3 \times 2.3 \text { m layers }) \\
\text { top/middle layers only }\end{array}$ & Yes & 0.9 \\
\hline
\end{tabular}

\subsection{Comparison of Cases WF31 and WF25-Old Versus New Trench Designs}

At a recharge rate of $4.2 \mathrm{~mm} / \mathrm{yr}$, the normalized technetium flux to the vadose zone is slightly less with the new, three-layer design (Figure 5). The slight decrease in technetium release occurs despite the fact the calculated $\mathrm{pH}$ for the new disposal facility design is 0.1 to $0.2 \mathrm{pH}$ units higher than it was with the old four-layer design (see Figure 6). The higher $\mathrm{pH}$ results from sodium ion exchange as water contacts more glass along the flow path in the new design $(3 \times 2.3 \mathrm{~m}=6.9 \mathrm{~m}$ of glass $)$ than in the old $(4 \times 1.4 \mathrm{~m}=5.6 \mathrm{~m}$ of glass). In accordance with the kinetic rate law for glass dissolution, the increase in $\mathrm{pH}$ should cause a 12 to $25 \%$ increase in glass corrosion rate and hence in the technetium release rate. Instead, the opposite trend is observed. The decrease in technetium release occurs because the new three-layer design has fewer interfaces with the backfill, where the $\mathrm{SiO}_{2}(\mathrm{aq})$ concentrations decrease sharply. As shown in Figure 7, the glass saturation index (hence corrosion rate) transitions sharply at the backfill/ glass interfaces in accordance with the steep gradient in $\mathrm{SiO}_{2}(\mathrm{aq})$ concentration. Because the glass corrosion rate is significantly higher at these interfaces, one less interface with the three-layer design offsets the effect of the slightly higher $\mathrm{pH}$. 


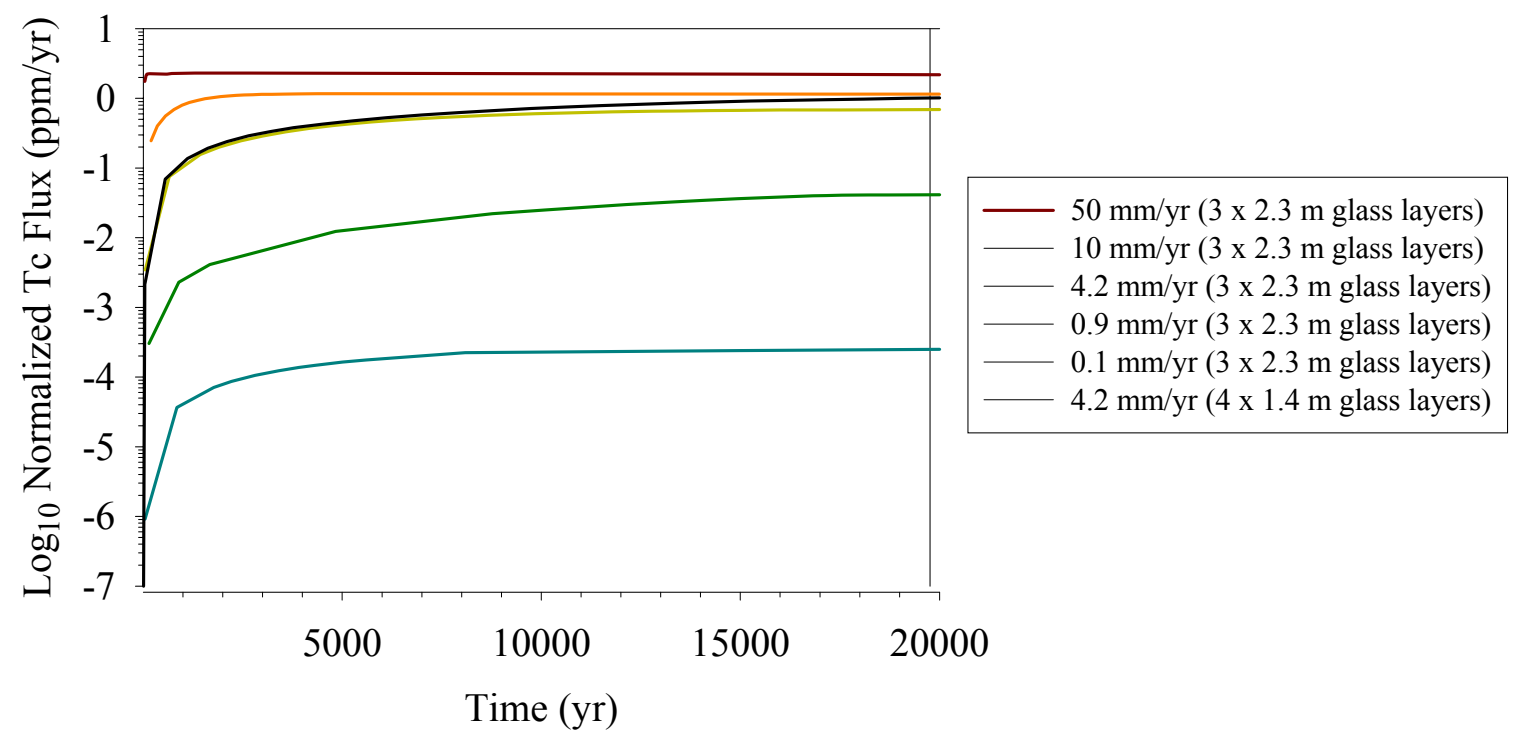

Figure 5. Technetium Fluxes Through Bottom of Disposal Facility for Different Recharge Rates; results for three 2.3-m glass layers (new design) and four 1.4-m glass layers (configuration used in 2001 ILAW PA) are compared

\subsection{Comparison of Cases WF31 Through WF35-Variations in Recharge Rate}

As shown in Figure 5, the effect of water recharge rate on normalized technetium flux to the vadose zone is very similar to that observed in calculations for the 2001 ILAW PA. The flux of technetium increases with increasing recharge rate. Higher recharge rates flush dilute water through the system, increasing water content in the glass layers and lowering the $\mathrm{SiO}_{2}(\mathrm{aq})$ concentration, thus increasing the glass dissolution rate. However, the dilution effect of higher recharge also limits increases in $\mathrm{pH}$, thereby limiting increases in the glass dissolution rate.

\subsection{Comparison of Cases WF33, WF36 and WF37_Effect of Missing Layers}

Simulations at a recharge rate of $0.9 \mathrm{~mm} / \mathrm{yr}$, comparing the effect of removing the middle or bottom layer in the new design, again show that the number and configuration of glass layers has only a slight effect on normalized flux (Figure 8). The highest technetium flux occurs in the case with the top and bottom layer only. The thick layer of backfill between glass layers in the top/middle case delays the time for the upper glass layer to affect the solution chemistry (primarily silicon concentration) at the backfill/ glass interface of the bottom layer. Consequently, a higher glass dissolution rate is maintained at early times in the bottom glass layer than where layers are closer together (top/middle case). However, the observed changes are small because the technetium concentrations (Figure 9) and pH (Figure 10) in the individual glass layers are largely independent and dominated by transport behavior at the backfill/glass interface. Again, the LAWABP1 glass dissolution rate is controlled by equilibrium with amorphous silica and is very close to saturation (Figure 11) in each case, except near the backfill/glass interfaces. 


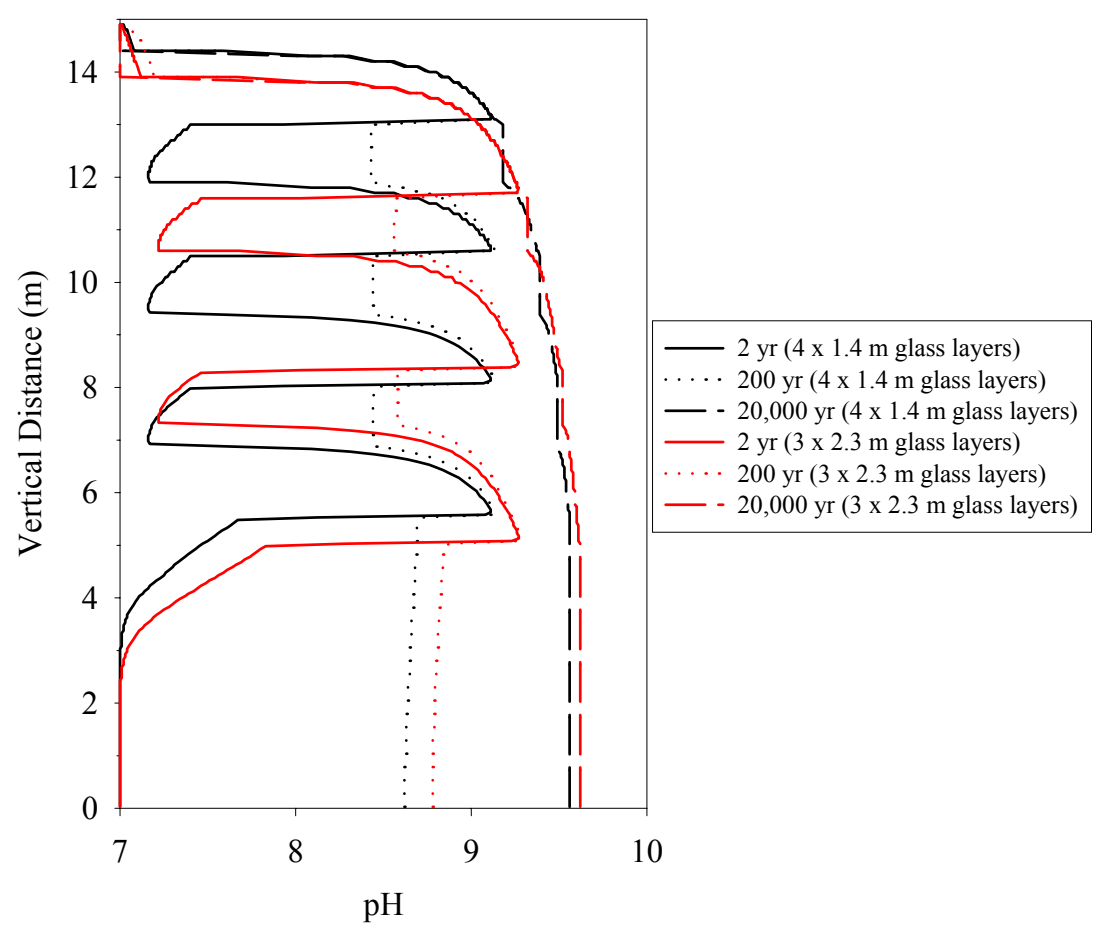

Figure 6. Aqueous $\mathrm{pH}$ in Disposal Facility; results for 4.2-mm/yr recharge with three 2.3-m glass layers (new design) and four 1.4-m glass layers (2001 ILAW PA configuration) compared

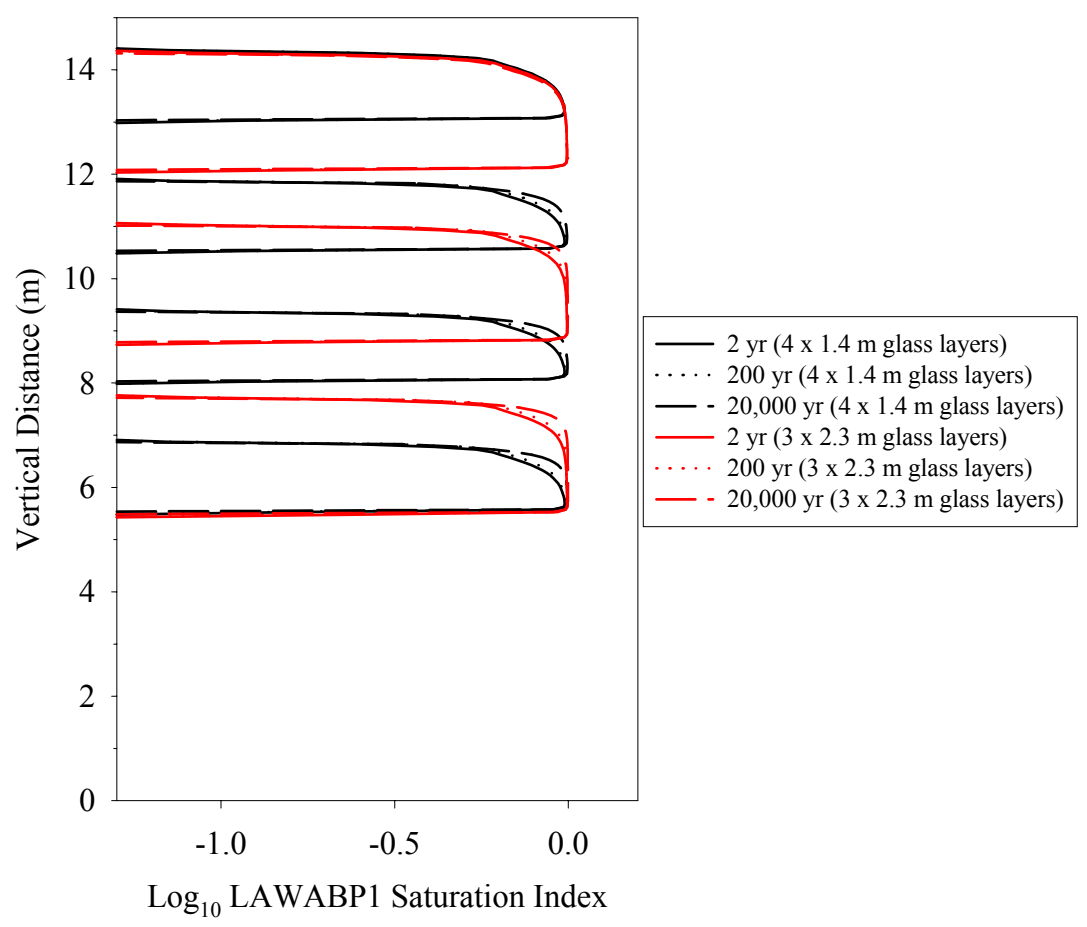

Figure 7. Saturation Index in Disposal Facility; results of $4.2 \mathrm{~mm} / \mathrm{yr}$ recharge with three $2.3-\mathrm{m}$ glass layers (new design) and four 1.4-m glass layers (2001 ILAW PA configuration) compared 


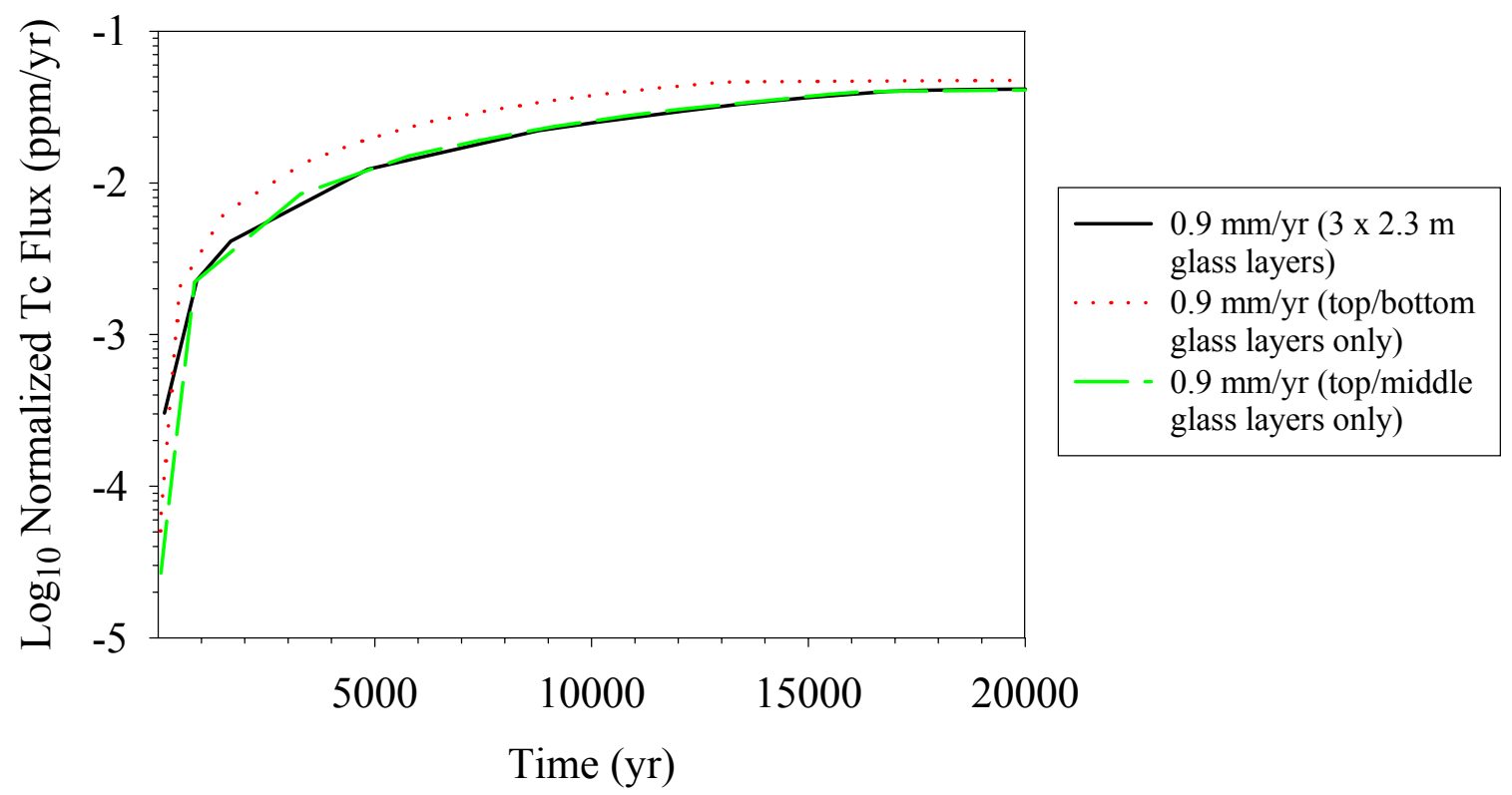

Figure 8. Technetium Fluxes Through Bottom of Disposal Facility for Various Recharge Rates; results for $0.9-\mathrm{mm} / \mathrm{yr}$ recharge with three 2.3-m glass layers (new design) compared with two 2-layer configurations

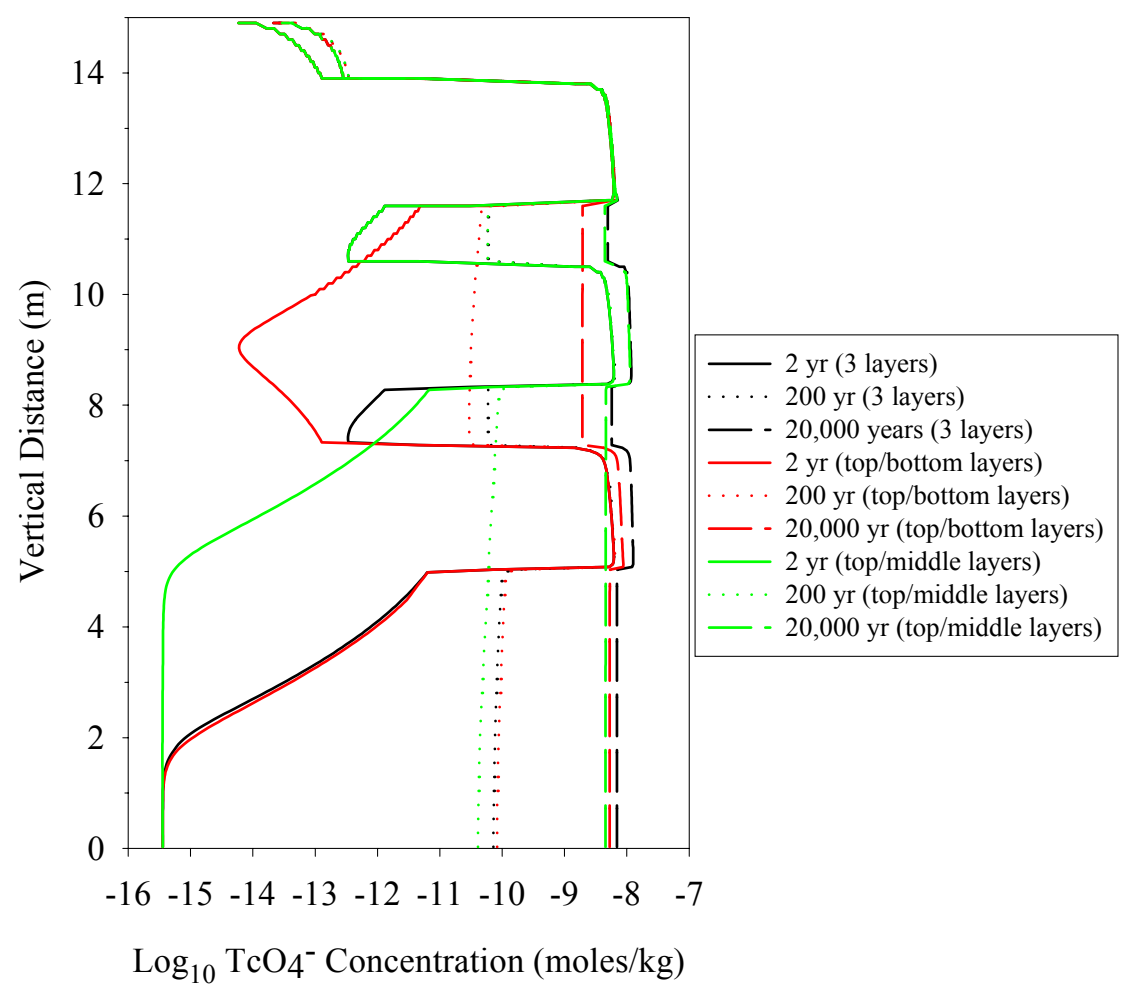

Figure 9. Technetium Concentrations in Disposal Facility; results for 0.9-mm/yr recharge with three 2.3-m glass layers (new design) are compared with two 2-layer configurations 


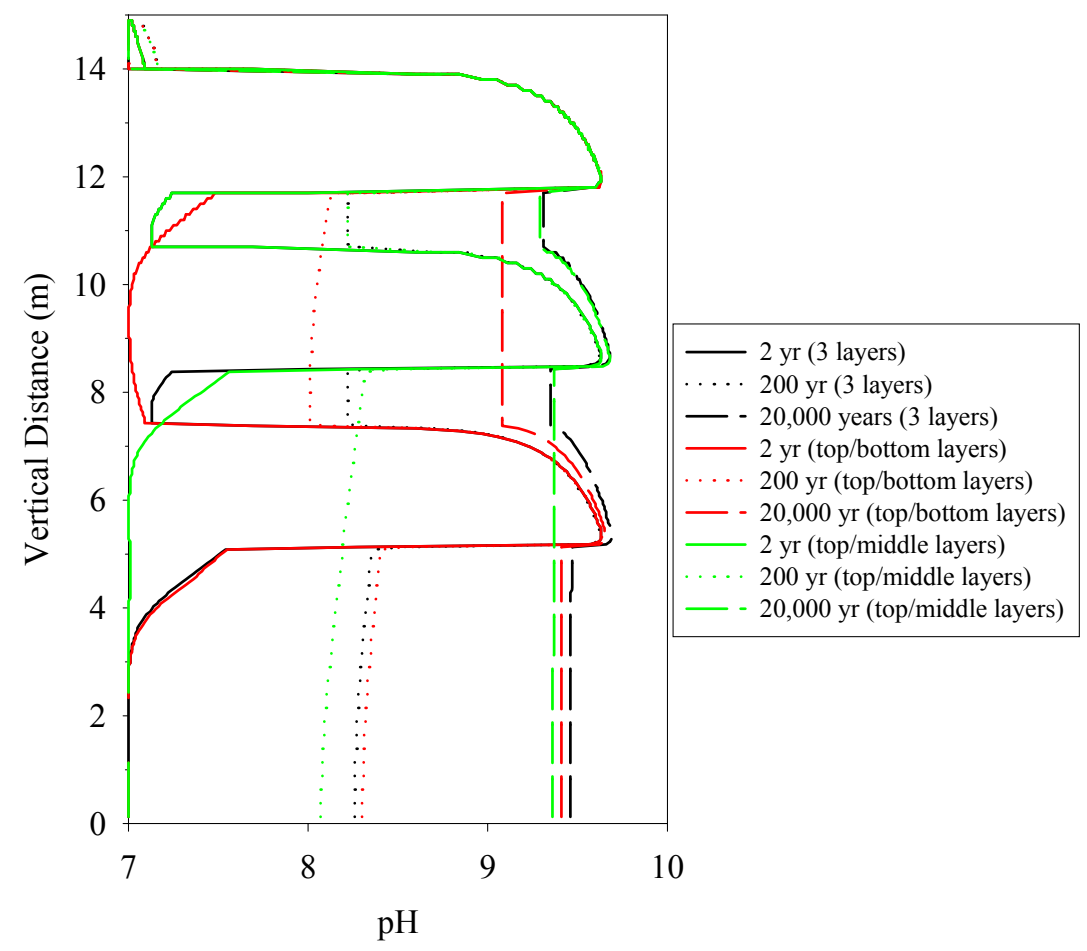

Figure 10. Aqueous $\mathrm{pH}$ in Disposal Facility at Several Times; results for $0.9 \mathrm{~mm} / \mathrm{yr}$ recharge with three 2.3-m glass layers (new design) compared with two 2-layer configurations

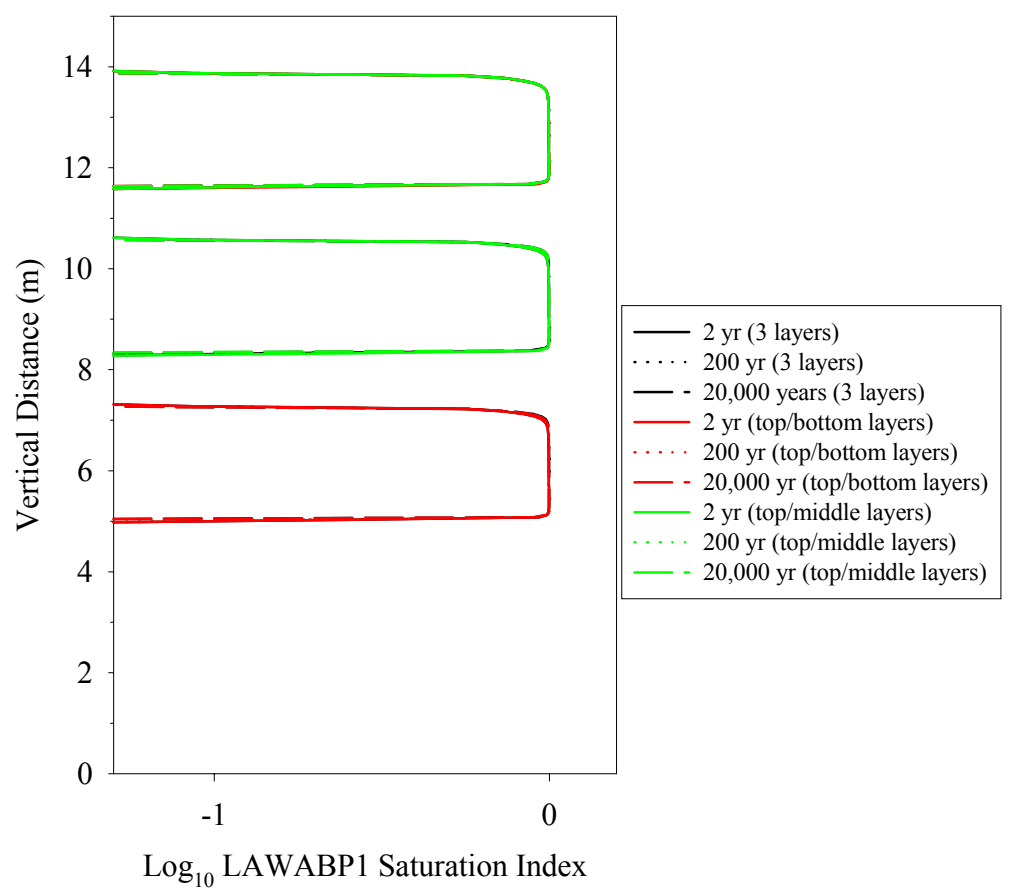

Figure 11. LAWABP1 Saturation Index in Disposal Facility; results for $0.9 \mathrm{~mm} / \mathrm{yr}$ recharge with three 2.3-m glass layers (new design) compared with two 2-layer configurations 


\subsection{Conclusions}

Table 13 summarizes the design change impacts relative to the base analysis case in the 2001 ILAW PA. The one-dimensional simulations predict a lower release rate for the new three-layer trench design $(0.605 \mathrm{ppm} / \mathrm{yr})$ than for the old four-layer design $(0.726 \mathrm{ppm} / \mathrm{yr})$. Because the glass corrosion rate is significantly higher at the backfill/glass interfaces, one less interface offsets the effect of the slightly higher $\mathrm{pH}$ with the three-layer design. The differences between the old and new trench designs were much less significant than differences due to changes in recharge rate. 
Table 13. Summary of New One-Dimensional ILAW Sensitivity Cases

\begin{tabular}{|c|c|c|c|c|c|}
\hline Description & $\begin{array}{l}\text { Normalized Flux } \\
\text { (1,000 yr } \\
\text { (ppm/yr) }\end{array}$ & $\begin{array}{l}\text { Normalized Flux } \\
\text { @ 10,000 yr } \\
(\mathbf{p p m} / \mathbf{y r})\end{array}$ & $\begin{array}{l}\text { Normalized Flux } \\
\text { Ratio@1,000 yr }\end{array}$ & $\begin{array}{c}\text { Normalized Flux } \\
\text { Ratio@10,000 yr }\end{array}$ & $\begin{array}{l}\text { Reason higher or lower } \\
\text { than base case }\end{array}$ \\
\hline $4.2 \mathrm{~mm} / \mathrm{y}$ infiltration & 0.120 & 0.710 & 1.0000 & 1.0000 & 2001 ILAW PA base case \\
\hline $\begin{array}{l}\text { Old design ( } 4 \text { x } 1.4 \text { m layers }) \\
\text { include steel in waste packages }\end{array}$ & 0.124 & 0.726 & 1.0288 & 1.0219 & steel corrosion increases $\mathrm{pH}$ \\
\hline $\begin{array}{l}\text { New design ( } 3 \times 2.3 \text { m layers }) \\
4.2 \mathrm{~mm} / \mathrm{yr}\end{array}$ & 0.112 & 0.605 & 0.9339 & 0.8520 & $\begin{array}{l}\text { glass corrosion limited by } \\
\text { silica equilibrium but more } \\
\text { glass in profile }\end{array}$ \\
\hline $\begin{array}{l}\text { New design ( } 3 \times 2.3 \mathrm{~m} \text { layers }) \\
0.1 \mathrm{~mm} / \mathrm{yr}\end{array}$ & $4.26 \mathrm{E}-05$ & $2.29 \mathrm{E}-04$ & 0.0004 & 0.0003 & lower recharge \\
\hline $\begin{array}{l}\text { New design ( } 3 \times 2.3 \text { m layers }) \\
0.9 \mathrm{~mm} / \mathrm{yr}\end{array}$ & $2.54 \mathrm{E}-03$ & $2.49 \mathrm{E}-02$ & 0.0211 & 0.0350 & lower recharge \\
\hline $\begin{array}{l}\text { New design ( } 3 \times 2.3 \mathrm{~m} \text { layers }) \\
10 \mathrm{~mm} / \mathrm{yr}\end{array}$ & 0.806 & 0.116 & 6.7043 & 1.6305 & higher recharge \\
\hline $\begin{array}{l}\text { New design ( } 3 \times 2.3 \mathrm{~m} \text { layers }) \\
50 \mathrm{~mm} / \mathrm{yr}\end{array}$ & 2.29 & 2.26 & 19.0385 & 3.1861 & higher recharge \\
\hline $\begin{array}{l}\text { New design }(3 \times 2.3 \mathrm{~m} \text { layers }) \\
0.9 \mathrm{~mm} / \mathrm{yr} \text {, top/bottom layers } \\
\text { only }\end{array}$ & $4.18 \mathrm{E}-03$ & $3.77 \mathrm{E}-02$ & 0.0348 & 0.0530 & $\begin{array}{l}\text { lower recharge, less glass in } \\
\text { profile }\end{array}$ \\
\hline $\begin{array}{l}\text { New design }(3 \times 2.3 \mathrm{~m} \text { layers }) \\
0.9 \mathrm{~mm} / \mathrm{yr} \text {, top/middle layers } \\
\text { only }\end{array}$ & $2.63 \mathrm{E}-03$ & $2.56 \mathrm{E}-02$ & 0.0218 & 0.0361 & $\begin{array}{l}\text { lower recharge, less glass in } \\
\text { profile }\end{array}$ \\
\hline
\end{tabular}




\subsection{References}

Auclair K and M Thien. 2000. Interface Control Document for Immobilized Low-Activity Waste. BNFL-5193-ID-15 Rev. 5, BNFL, Inc., Richland, WA.

Bacon DH and BP McGrail. 2001. Waste Form Release Calculations for the 2001 Immobilized LowActivity Waste Performance Assessment. PNNL-13369, Pacific Northwest National Laboratory, Richland, WA.

Bacon DH, MD White, and BP McGrail. 2000. Subsurface Transport over Reactive Multiphases (STORM): A General, Coupled, Nonisothermal Multiphase Flow, Reactive Transport, and Porous Medium Alteration Simulator, Version 2, User's Guide. PNNL-13108, Pacific Northwest National Laboratory, Richland, WA.

Burbank DA. 2001. Conceptual Design Report for the Immobilized Low-Activity Waste Disposal Facility, Project W-520. RPP-7908 Rev. 0, CH2MHILL Hanford Group, Inc., Richland, WA.

Cloke PL, DM Jolley, and DH Lester. 1997. Waste Package Development Design Analysis. BBA000000-01717-0200-0050 Rev. 00, CRWMS/M\&O, Las Vegas, NV.

Daveler SA and TJ Wolery. 1992. EQPT, A Data File Preprocessor for the EQ3/6 Software Package: User's Guide and Related Documentation (Version 7.0). UCRL-MA-110662 PT II, Lawrence Livermore National Laboratory, Livermore, CA.

Farnsworth RK, MKW Chan, and SC Slate. 1985. "The Effect of Radial Temperature Gradients on Glass Fracture in Simulated High-Level Waste Canisters." Proc. Mat. Res. Soc. Symp, 44:831-838.

Fayer MJ, EM Murphy, JL Downs, FO Khan, CW Lindenmeier, and BN Bjornstad. 1999. Recharge Data Package for the Immobilized Low-Activity Waste 2001 Performance Assessment. PNNL-13033, Pacific Northwest National Laboratory, Richland, WA.

Grenthe I, J Fuger, RJM Konings, RJ Lemire, AB Muller, C Nguyen-Trung, and H Wanner. 1992. Chemical Thermodynamics, Volume 1: Chemical Thermodynamics of Uranium. North Holland, Amsterdam.

Kaplan DI and RJ Serne. 1999. Geochemical Data Package for the Hanford Immobilized Low-Activity Tank Waste Performance Assessment (ILAW-PA). PNNL-13037, Pacific Northwest National Laboratory, Richland, WA.

Khaleel R. 1999. Far-Field Hydrology Data Package for Immobilized Low-Activity Tank Waste Performance Assessment. HNF-4769 Rev. 1, Fluor Daniel Northwest, Inc., Richland, WA.

Mann FM, KC Burgard, WR Root, RJPuigh II, SH Finfrock, R Khaleel, DH Bacon, EJ Freeman, BP McGrail, SK Wurstner, and PE Lamont. 2001. Hanford Immobilized Low-Activity Waste Performance Assessment: 2001 Version. DOE/ORP-2000-24 Rev. 0, U.S. Department of Energy Office of River Protection, Richland, WA.

Mann FM, RJ Puigh, II, CR Eiholzer, Y Chen, NW Kline, AH Lu, BP McGrail, PD Rittmann, GF Williamson, NR Brown, and PE LaMont. 1998. Hanford Immobilized Low-Activity Tank Waste Performance Assessment. DOE/RL-97-69 Rev. B, Project Hanford Management Contractor, Richland, WA. 
McGrail BP and DH Bacon. 1998. Selection of a Computer Code for Hanford Low-Level Waste Engineered System Performance Assessment. PNNL-10830 Rev. 1, Pacific Northwest National Laboratory, Richland, WA.

McGrail BP, DH Bacon, JP Icenhower, WL Ebert, PF Martin, HT Schaef, and EA Rodriguez. 2000. Waste Form Release Data Package for the 2001 Immobilized Low-Activity Waste Performance Assessment. PNNL-13043 Rev. 1, Pacific Northwest National Laboratory, Richland, WA.

McGrail BP, DH Bacon, JP Icenhower, WL Ebert, PF Martin, HT Schaef, and EA Rodriguez. 2001. Waste Form Release Data Package for the 2001 Immobilized Low-Activity Waste Performance Assessment. PNNL-13043 Rev. 2, Pacific Northwest National Laboratory, Richland, WA.

Meyer PD and RJ Serne. 1999. Near-Field Hydrology Data Package for the Immobilized Low-Activity Waste 2001 Performance Assessment. PNNL-13035, Richland, WA.

Peters RD and SC Slate. 1981. "Fracturing of Simulated High-Level Waste Canisters." Nuc. Eng. Design, 67:425-445.

Puigh RJ. 1999. Disposal Facility Data for the Hanford Immobilized Low-Activity Tank Waste. HNF-4950 Rev. 0, Fluor Federal Services, Richland, WA.

Shock EL and HC Helgeson. 1988. "Calculation of the thermodynamic and transport properties of aqueous species at high pressures and temperatures: Correlation algorithms for ionic species and equation of state predictions to $5 \mathrm{~kb}$ and $1000^{\circ}$ C." Geochim. Cosmochim. Acta, 52:2009-2036.

Shock EL, HC Helgeson, and DA Sverjensky. 1989. "Calculation of the thermo-dynamic and transport properties of aqueous species at high pressures and temperatures: Standard partial molal properties of inorganic neutral species." Geochim. Cosmochim. Acta, 53:2157-2183.

Sverjensky D and N Sahai. 1996. "Theoretical prediction of single-site surface-protonation equilibrium constants for oxides and silicates in water." Geochim. Cosmochim. Acta, 60:3773-3797.

Wolery TJ and SA Daveler. 1992. EQ6, A Computer Program for Reaction Path Modeling of Aqueous Geochemical Systems: Theoretical Manual, User's Guide, and Related Documentation (Version 7.0). UCRL-MA-110662 PT IV, Lawrence Livermore National Laboratory, Livermore, CA.

Wootan DW. 1999. Immobilized Low-Activity Tank Waste Inventory Data Package. HNF-4921 Rev. 0, Fluor Daniel Northwest, Inc., Richland, WA. 


\section{Distribution}

No. of

Copies

Offsite

Dr. Harry Babad

2540 Cordoba $\mathrm{Ct}$

Richland, WA 99352

William L. Ebert

Argonne National Laboratory

Building 205

9700 South Cass Avenue

Argonne, IL 60439-4837

Ian L. Pegg

Catholic University of America

Vitreous State Laboratory

Washington D.C. 20064

2 Westinghouse Savannah River Co.

P. O. Box 616

Aiken, SC 29802

Attn: E. W. Holtzscheiter

D. K. Peeler

\section{Onsite}

3 DOE Richland Operations Office

P. E. Lamont

H6-60

C. A. Babel

Public Reading Room
No. of

Copies

2 Fluor Federal Services

R. Khaleel

E6-17

R. J. Puigh

E6-17

2 CH2M HILL

F. M. Mann (2)

E6-35

$\underline{\text { DFSNW }}$

C. N. Wilson

H1-11

20 Pacific Northwest National Laboratory

D. H. Bacon (5) K9-33

S. Q. Bennett K7-90

M. J. Fayer K9-33

J. P. Icenhower K6-81

P. F. Martin K6-81

B. P. McGrail (2) K6-81

P. D. Meyer BPO

E. A. Rodriguez K6-81

K. P. Saripalli K6-81

H. T. Schaef K6-81

R. J. Serne K6-81

J. L. Steele K6-81

J. D. Vienna K6-24

Information Release Office (2) K1-06

Distr.1 